\title{
Recruitment of the Pacific oyster Crassostrea gigas in a shellfish-exploited Mediterranean lagoon: discovery, driving factors and a favorable environmental window
}

\author{
Franck Lagarde ${ }^{1, *}$, Emmanuelle Roque d'orbcastel ${ }^{1}{ }$, Martin Ubertini $^{1}$, Serge Mortreux ${ }^{1}$, \\ Ismaël Bernard ${ }^{2}$, Annie Fiandrino ${ }^{1}$, Claude Chiantella ${ }^{1}$, Béatrice Bec $^{3}$, Cécile Roques ${ }^{3}$, \\ Delphine Bonnet ${ }^{3}$, Gilles Miron ${ }^{4}$, Marion Richard ${ }^{1}$, Stéphane Pouvreau ${ }^{5}$, Christophe Lett ${ }^{6}$ \\ ${ }^{1}$ Ifremer/UMR MARBEC, Ifremer, 34200 Sète, France \\ ${ }^{2}$ Eureka Modélisation, 22740 Lézardrieux, France \\ ${ }^{3}$ Université de Montpellier/UMR MARBEC, 34095 Montpellier, France \\ ${ }^{4}$ Université de Moncton, New Brunswick E1A 3E9, Canada \\ ${ }^{5}$ Ifremer/UMR LEMAR, Technopole de Brest-Iroise, 29280 Plouzané, France \\ ${ }^{6}$ IRD/UMI ummisco, 34200 Sète, France
}

\begin{abstract}
In the context of increasing demand for environmental recovery, aquatic systems may face the challenge of evolving under oligotrophication. This is the case in Mediterranean lagoons, in particular the shellfish-farmed Thau lagoon in France, where we studied recruitment of the Pacific oyster Crassostrea gigas. Oyster spat and environmental parameters were monitored at several sampling sites for 3 yr (2012 to 2014) using an original method with a temporal overlap deployment of collectors to study pre- and post-settlement processes and to identify the best conditions for recruitment. Contrary to the 'no Pacific oyster reproduction' paradigm in Mediterranean lagoons, our study showed that recruitment of this introduced species is possible in the Thau lagoon at levels comparable to those in other traditional French breeding basins. We identified a favorable environmental window for recruitment characterized by high water temperature $\left(>26.5^{\circ} \mathrm{C}\right)$ and high nanophytoplankton and Chaetoceros spp. abundances $\left(>4.3 \times 10^{6}\right.$ and 345 $\times 10^{3}$ cells $^{l^{-1}}$, respectively). In these favorable conditions, we hypothesize that the ecosystem functions as an autotrophic system, in contrast to the heterotrophic system that characterizes unfavorable conditions. Under heterotrophic conditions, high abundances of mixotrophic and heterotrophic organisms (ciliates and dinoflagellates) limited the metamorphosis of C. gigas larvae, leading to poor recruitment. This study provides new knowledge on the reproduction of the Pacific oyster in a Mediterranean lagoon under warming and oligotrophication. The shellfish industry will profit from the discovery of spatfields to develop new nursery practices that are eco-friendly and limit risks of transfers with other spatfall areas.
\end{abstract}

${ }^{*}$ Corresponding author: franck.lagarde@ifremer.fr

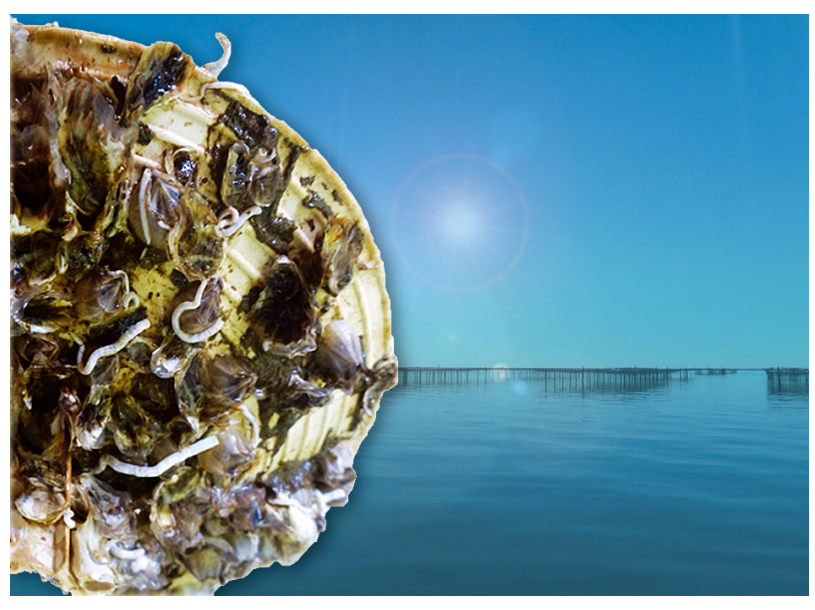

Discovery of oyster spat recruitment in the French Mediterranean Thau lagoon.

Photo: (UUMR MARBEC

KEY WORDS: Crassostrea gigas - Oyster spat · Pediveliger - Metamorphosis - Recruitment - Oligotrophication $\cdot$ Larval ecology

\section{INTRODUCTION}

Ecosystems change over time under the constraints of combined global warming and anthropogenic impacts. More visible than global warming, marked local effects due to coastal urban development and/ or pollution lead to environmental changes that seriously affect ecological processes. Hence, the increase

() The authors 2017. Open Access under Creative Commons by Attribution Licence. Use, distribution and reproduction are unrestricted. Authors and original publication must be credited. 
in nutrient intakes in recent decades has led to the eutrophication of aquatic ecosystems (Nixon 1995, De Jonge \& Elliott 2001, Smith \& Schindler 2009). In the context of increasing demand for the recovery of ecosystem services (Bullock et al. 2011) and good environmental status (Vethaak et al. 2017), these ecosystems now face the challenge of evolving under oligotrophication (Jeppesen et al. 1998, 2005, Duarte et al. 2009, Yanagi 2015).

Oligotrophication (Cloern 2001, Boesch 2002) caused by ecosystem and wastewater management (Leruste et al. 2016) and increasing temperature (Collos et al. 2009) are 2 major trends that have been observed in Mediterranean lagoons. Oligotrophication causes a shift in the structure of the phytoplankton community from diatoms, cryptophytes and green algae to mixotrophic dinophytes (Leruste et al. 2016, Gowen et al. 2015). The combination of global warming and reduced nutrient loads may lower phytoplankton biomass (Collos et al. 2009, Lie et al. 2011, Saeck et al. 2013). This reduction may affect the breeding stocks of bivalve suspension feeders in shellfish basins (Dame 2011), possibly jeopardizing their sustainability.

The Pacific oyster Crassostrea gigas is one of the most economically important invertebrate species. According to FAO Fishery Statistics, the global production of this species was estimated to have reached 4.4 million t by 2003 and its global aquaculture production to be $625925 \mathrm{t}$ in 2014 (http://www.fao.org/ fishery/culturedspecies/Crassostrea_gigas/en). This oyster species was introduced into France in 1970 for social and economic reasons (Grizel \& Héral 1991) and was highly productive from the 1980s onwards in both the Atlantic and Mediterranean (Héral \& DeslousPaoli 1991, Deslous-Paoli et al. 1993). About $10 \%$ of French oyster production comes from the Mediterranean Thau lagoon (Robert et al. 2013), located in southern France.

C. gigas has been widely studied all over the world, and its life history (reproduction, larval cycle and recruitment phase) has been relatively well described in both controlled environments (Fabioux et al. 2005, Enriquez-Diaz et al. 2009, Rico-Villa et al. 2010) and coastal tidal ecosystems (Dutertre et al. 2010, Thomas et al. 2016, Bernard et al. 2016). Fewer studies have been conducted in nanotidal environments such as Mediterranean lagoons (Tagliapietra \& Ghirardini 2006). The gametogenesis and spawning behavior of C. gigas were only recently explored in the Thau lagoon by Ubertini et al. (2017). According to these authors, the spawning behavior of C. gigas within Thau lagoon appeared to be slightly different from that on the Atlantic coast, with several spawning events occurring from June to October. The minimal temperature observed for spawning was $23^{\circ} \mathrm{C}$, which is much higher than the temperature mentioned in the literature for this species. Additionally, a strong relationship was found between phytoplankton communities and gametogenesis, the latter being improved by a higher diatom/dinoflagellate ratio.

The Mediterranean oyster industry is based on spat supplied from Atlantic nursery basins (mainly Arcachon and Marennes-Oléron) and hatcheries (Buestel et al. 2009). The massive spat mortality observed in France since 2008 (Pernet et al. 2010, 2012 , 2014) emphasized the dependence of the Mediterranean industry on outside sources, highlighting the need for a native supply. However, reproduction of $C$. gigas is believed to be impossible (Debos et al. 1972, Drullion 2002) or irregular (Goulletquer 1995) in the Thau lagoon, possibly due to unfavorable hydrological conditions (e.g. temperature, salinity, insufficient food and high concentrations of antifouling paint) (Deslous-Paoli et al. 1982, His \& Robert 1985, His et al. 1986).

A limited number of studies on marine invertebrates have suggested that recruitment in the Thau lagoon is highly spatially heterogeneous, potentially related to plankton depletion due to intensive shellfish culture (Lam-Hoai et al. 1997, Souchu et al. 2001) and hydrodynamic circulation (Borsa \& Millet 1992). However, recruitment information on C. gigas in the Thau lagoon remains limited, and the aim of the present work was to fill this gap.

To this end, several larval and oyster spat monitoring sites were created at different locations in the Thau lagoon to precisely monitor both pelagic larval phases and benthic settlement of $C$. gigas over a period of $3 \mathrm{yr}$. The general hypothesis of this study is that the 'no-recruitment' paradigm in Mediterranean lagoons is false, and that lagoon ecology offers recruitment windows, in the general concept of several conceptual frameworks such as supply-side ecology (Grosberg \& Levitan 1992), match-mismatch (Cushing 1990), transport and retention (Bishop et al. 2006). Our objectives were to (1) identify patterns of oyster recruitment in space and over time, (2) characterize variations within different pelagic and benthic larval stages and (3) explore the effects of environmental factors on larval development and recruitment success. Using a correlative approach, we paid particular attention to the food sources known to play a major role in the development of bivalve mollusk larvae (His et al. 1989, His \& Seaman 1992). 


\section{MATERIALS AND METHODS}

\section{Study site}

The Thau lagoon is the largest nanotidal lagoon in the Occitanian region in southern France (Fig. 1). It covers an area of 7500 ha $(19 \times 4.5 \mathrm{~km})$ on a northeast-southwest axis and has a mean depth of $3.5 \mathrm{~m}$. Seawater inputs from the Mediterranean Sea enter by artificial channels. Four spatfall sites (Fig. 1) were monitored to assess pre-settled oyster larvae and post-settled spat abundances in pelagic and benthic habitats: 3 inside shellfish-farming zones (Bouzigues, Meze and Marseillan) and one outside (Listel).

\section{Larval and spat abundances}

Crassostrea gigas pelagic and benthic larval abundances were assessed from June to September in 2012, 2013 and 2014. Pelagic larvae assessments were carried out twice a week using a standard protocol provided by the National Larval Network (Pouvreau et al. 2013, 2016) where the size of 'D-larvae' varies between 60 and $100 \mu \mathrm{m}$ and 'large umbo larvae'

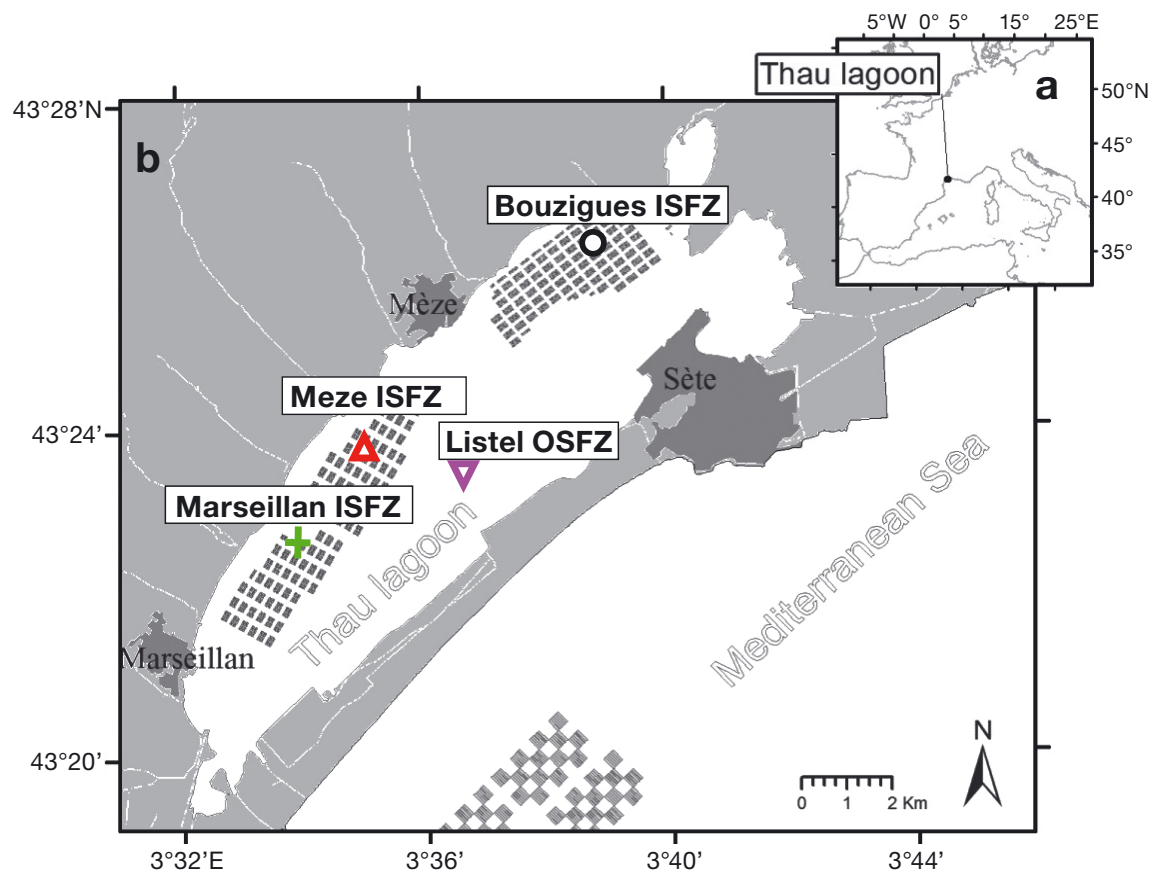

Fig. 1. (a) The Mediterranean Thau lagoon in France and (b) sampling sites within the Thau lagoon. Labelled are the 4 sampling sites (Marseillan, green cross; Meze, red triangle; Bouzigues, black open circle; and Listel, purple triangle) where pelagic and benthic Pacific oyster larvae, spat abundances, hydrological and plankton data were monitored. ISFZ: Inside the shellfish farmed zone (monitoring took place under farmed structures); OSFZ: outside the shellfish farmed zone (monitoring took place at specially designed mooring systems, see Fig. 2a). Grey boxes: shellfish farms; dark grey areas: towns between 180 and $300 \mu \mathrm{m}$. A sampling volume of $1.5 \mathrm{~m}^{3}$ was pumped and filtered through a $40 \mu \mathrm{m}$ plankton net.

Benthic oyster abundances were estimated every 2 wk at 3 different settler stages: pre-settled larvae, young postlarvae and newly-settled spat (Arakawa 1990). An original method with a temporal overlap of collector deployment was used (Hughes et al. 2000, Arnold \& Steneck 2011). Pediveligers were observed on the collectors' plates, with prodissochonch 2 shell size ranging from 180 to $300 \mu \mathrm{m}$. This pediveliger stage precedes metamorphosis, a vulnerable phase of their life cycle (Coon et al. 1990, Pechenik 2006). The main physiological transformations of metamorphosis are complex (Bishop et al. 2006), basically converting the larval body plan into an adult body plan (Wray 1995). In bivalves, the evolution of important organs such as gills during metamorphosis remarkably affects the feeding mechanism (Veniot et al. 2003, Cannuel \& Beninger 2007, Cannuel et al. 2009). Metamorphosis is defined as the transformation of pediveliger into postlarvae. Postlarvae are strictly benthic and cemented with a dissoconch shell. Their size ranges from 300 to $1000 \mu \mathrm{m}$. Oyster spat follow postlarvae at 4 wk of age (maximum), with a size range from 1 to $8 \mathrm{~mm}$. To collect these benthic stages, the sites were equipped with 3 replicated sets of 2 collectors (Fig. 2). Each collector was composed of 44 white plates (15 $\mathrm{cm}$ diameter; $250 \mathrm{~cm}^{2}$ ), measuring $110 \mathrm{~cm}$ (Fig. 2). Collectors were vertically submerged $2 \mathrm{~m}$ below the surface, suspended under shellfish farming structures, or outside farming structures on specially designed mooring systems (Fig. 2a). The mooring systems were positioned so that the top of the uppermost collector was $2.5 \mathrm{~m}$ below the surface. The systems were designed to support 2 sets of collectors immersed for 4 wk at 2 wk intervals. Pediveliger and postlarvae abundance was assessed on the $2-w k$ collector and oyster spat abundance was assessed on the 4 -wk collector. The 4 -wk collector was replaced; therefore in the system 1 collector was replaced every 2 wk throughout the summer.

Each collector was sampled at 3 vertical levels: close to the top (39th plate), middle (22th plate) and bottom (5th plate). Both sides of the plates 

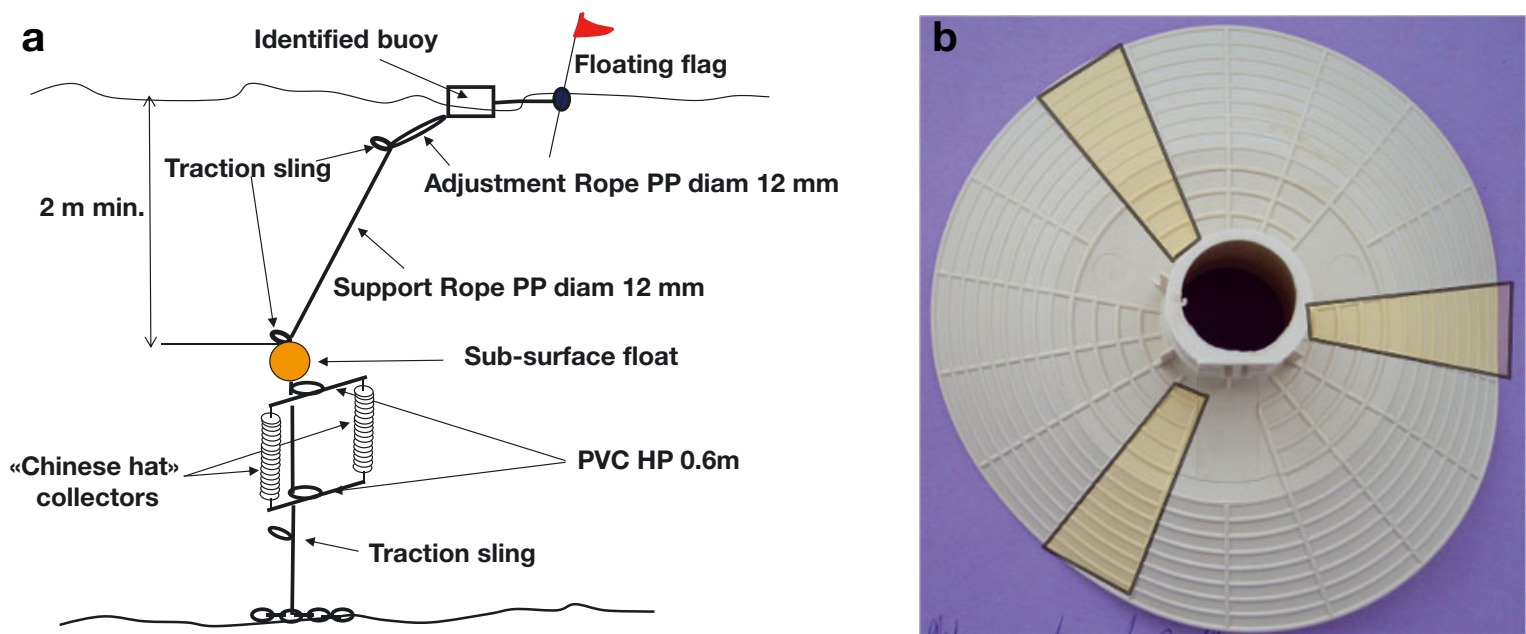

Fig. 2. (a) Mooring system used OSFZ in the Thau lagoon. The gear supported a set of 2 'Chinese hat' collectors with plates. The first collector was immersed for $2 \mathrm{wk}$ and the second for $4 \mathrm{wk}$ before being replaced by a new collector. The sampling period lasted from June to October. (b) Top view of a collector plate with counting subunits in yellow, in this case: $14 \mathrm{~cm}^{2}$

(above and below) were examined under a binocular microscope to assess the mean abundance of pediveligers, postlarvae and newly settled spat, or macroscopically when possible. On each occasion, counting was carried out on subunits, i.e. from 1 to 4 basic subunits (14 to $\left.56 \mathrm{~cm}^{2}\right)$, replicated 3 times per side (Fig. $2 \mathrm{~b}$ ), for a total of 54 counts by date and site ( 3 collectors $\times 3$ levels $\times 2$ sides $\times 3$ subunits). The abundance per plate was averaged from subunit counts and converted into total individual abundances per plate.

Pediveliger and spat abundances were classified in 5 categories according to a recruitment scale proposed by Pouvreau et al. (2013) for the French coast: zero (0 ind. plate $\left.{ }^{-1}\right)$, low ( 1 to 20 ind. plate ${ }^{-1}$ ), medium (21 to 200 ind. plate ${ }^{-1}$ ), high (201 to 2000 ind. plate ${ }^{-1}$ ) and overabundant (>2000 ind. plate ${ }^{-1}$ ). An additional qualitative recruitment factor was created to compare pediveliger (Pedi) and spat (Spat) abundances (Fig. 3). The recruitment factor terms 'Pedi-' and 'Spat-' summed the abundances from 0 to 20 ind. plate $^{-1}$, and Pedi+ and Spat+ summed the abundances $>20$ ind. plate ${ }^{-1}$. The recruitment factor combined terms to define 3 conditions: Pedi- indicated low pediveliger supplies, Pedi+Spat- indicated metamorphosis failure and Pedi+Spat+ indicated successful metamorphosis.

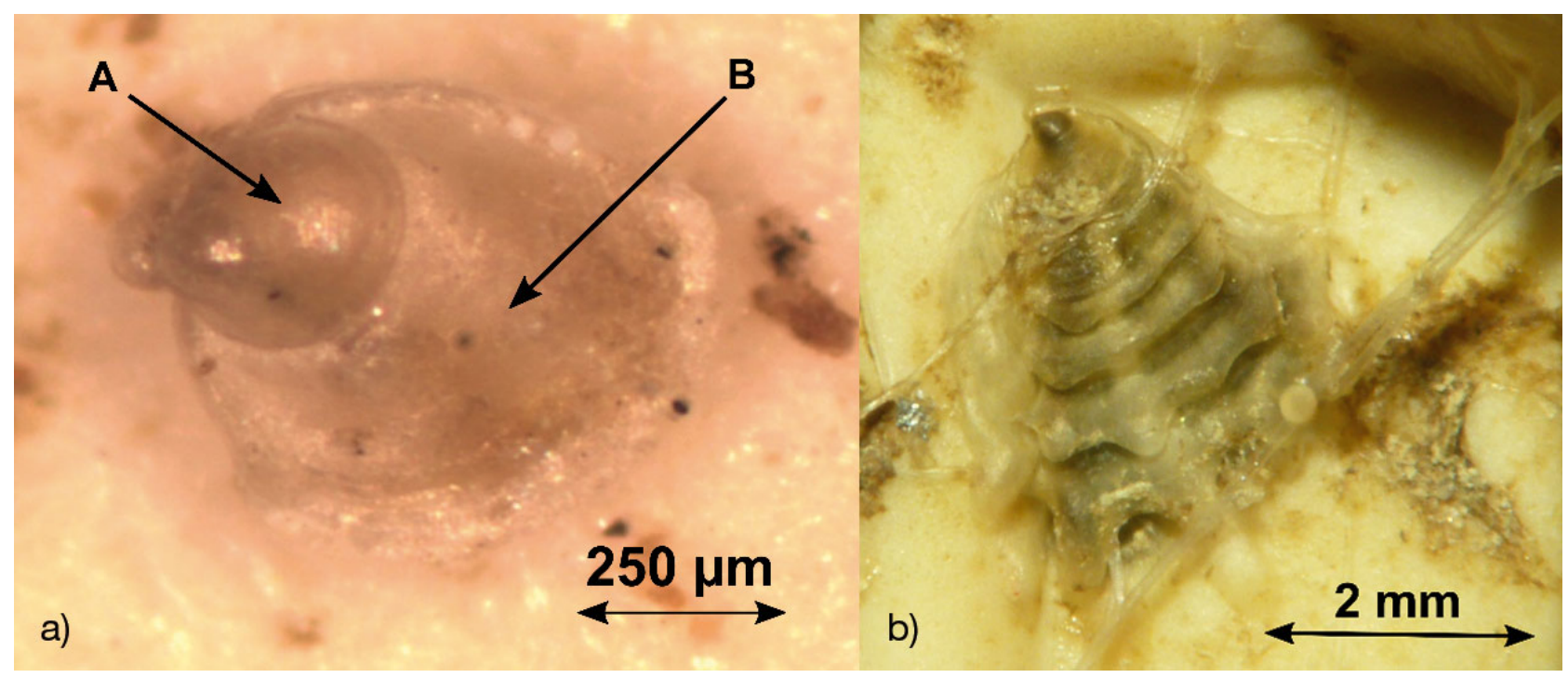

Fig. 3. Settled Pacific oyster larvae on a collector plate. (a) Shell of pre-settled larvae (pediveliger; A) and shell of young postlarvae after metamorphosis (B) on collectors immersed for $2 \mathrm{wk}$; and (b) newly-settled spat on a collector immersed for 4 wk 


\section{Environmental measurements}

Environmental parameters (hydrological and plankton samples) were recorded every Monday morning from first of June to the end of September in 2012, 2013 and 2014. Samples were taken on spatfall sites at Listel and Mèze. Bouzigues and Marseillan spatfall sites were located less than $1 \mathrm{~km}$ from where environmental measures were monitored (data from sampling sites for the REPHY dataset - French Observation and Monitoring program for Phytoplankton and Hydrology in coastal waters (2017) - were used in this study). For Bouzigues and Marseillan, hydrological and plankton samples associated with spatfall sampling sites were in biocoenosis, characterized by the same phytoplankton, zooplankton and benthic populations (Jarry et al. 1990, Jouffre et al. 1991, Guelorget et al. 1994).

\section{Hydrological monitoring}

Temperature and salinity were measured twice a week and weekly averaged with WTW ${ }^{\circledR}$ probes positioned between 1 and $1.5 \mathrm{~m}$ below the surface. Oxygen concentrations were measured once a week at the Bouzigues site at the bottom of the water column. Data were collected from June to September in 2012, 2013 and 2014.

\section{Plankton monitoring}

Our sampling strategy provided 135 observations: 3 sites $\times 15 \mathrm{wk} \times 3 \mathrm{yr}$. Each phytoplankton and protozooplankton sample was collected by sampling site and date using subsamples from a $4 \mathrm{l}$ sample. Samples were collected weekly using a Standard Water Sampler acc. to Ruttner (Hydro-Bios) at 3 sampling sites $\mathrm{yr}^{-1}$. No analytical replicates or sampling replicates were used. The Bouzigues, Meze and Marseillan sites were sampled in 2012, while the Bouzigues, Listel and Marseillan sites were sampled in 2013 and 2014.

For total chlorophyll a (total_chloa) measurements, seawater samples $(200 \mathrm{ml})$ were filtered (Bec et al. 2005 , 2011) under vacuum $(<10 \mathrm{~cm} \mathrm{Hg})$ on Whatman $\mathrm{GF} / \mathrm{F}$ membranes ( $0.7 \mu \mathrm{m}$ porosity) and stored in glass tubes at $-20^{\circ} \mathrm{C}$. Filters were ground in acetone $(90 \%)$ and extracted for $24 \mathrm{~h}$ at $4^{\circ} \mathrm{C}$ in the dark. Chl a biomass was also determined after size fractioning (200 $\mathrm{ml}$ for picophytoplankton and $200 \mathrm{ml}$ for nanophytoplankton from the 41 samples) through Nuclepore membranes ( 3 and $20 \mu \mathrm{m}$ ) to determine the con- tribution of picophytoplankton $(<3 \mu \mathrm{m})$, nanophytoplankton (3 to $20 \mu \mathrm{m}$ ) and microphytoplankton $(>20 \mu \mathrm{m})$ to total phytoplankton biomass. The pig-

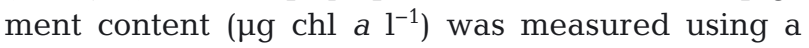
spectrofluorometer (Perkin-Elmer LS50b) (Neveux \& Lantoine 1993).

Abundances of picocyanobacteria $(<1 \mu \mathrm{m})$, autotrophic picoeukaryotes $(<3 \mu \mathrm{m})$ and nanophytoplankton ( 3 to $20 \mu \mathrm{m}$ ) were determined on the basis of a sampled volume of $1 \mathrm{ml}$ with a Becton Dickinson FACSCalibur flow cytometer (Bec et al. 2011). Total picophytoplankton abundances were estimated as the sum of the picocyanobacteria and picoeukaryote abundances. Among nanophytoplankton, cryptophytes were distinguishable from other photosynthetic organisms by their strong orange fluorescence and their size. Abundances were expressed in $10^{6}$ cells $^{-1}$.

To measure bacterial abundance, samples $(1 \mathrm{ml}$ from the 41 samples) were fixed with prefiltered $(0.2 \mu \mathrm{m})$ buffered formaldehyde $(2 \%$ final concentration) and stored in liquid nitrogen. Abundances were determined by a FACSCalibur flow cytometer Becton Dickinson method (Marie et al. 1997). The procedure was slightly modified as higher concentrations of fluorochrome (SYBR Green I) were used (Bouvy et al. 2016). A total of $1 \mathrm{ml}$ of fixed sample was incubated with SYBR Green I (Molecular Probes) at a final concentration of $1 / 375$ for $15 \mathrm{~min}$ at $4^{\circ} \mathrm{C}$ in the dark. Stained bacterial cells excited at $488 \mathrm{~nm}$ were determined according to their side-scattered light and green fluorescence collected using a 530/30 nm filter. Fluorescent beads ( $0.94 \mu \mathrm{m}$; Polysciences) were added to each sample.

Protozooplankton (heterotrophic flagellate, $30 \mathrm{ml}$ sample and ciliates, $100 \mathrm{ml}$ sample) and total phytoplankton flora (10 $\mathrm{ml}$ sample) were estimated using the standard Utermöhl method NF-EN-152014, 2006. For the total phytoplankton flora, 2 main classes ('diatoms', aggregating 52 taxa and 'dinoflagellates', aggregating 38 taxa) were first used to explore the dataset. In addition, we paid particular attention to the diatom genus Chaetocoeros spp. because of its high abundance and its known role in the biological cycle of oyster recruitment (Rico-Villa et al. 2006, Blanchard et al. 2008, Ben Kheder et al. 2010). Protozooplankton and total flora were expressed as the number of individuals per liter. Total phytoplankton flora were not monitored in 2012 at the Meze sampling site.

For analysis of the heterotrophic flagellate, the $30 \mathrm{ml}$ samples were preserved in an $8 \%$ formaldehyde solution and stored in a cold room at $4^{\circ} \mathrm{C}$ in the dark until analysis. A $10 \mathrm{ml}$ subsample was stained using 
4', 6-diamidino-2-phenylindole (DAPI) at a final concentration of $2.5 \mathrm{\mu g} \mathrm{ml}^{-1}$. The heterotrophic flagellate counts were performed using an epifluorescence microscope (Olympus AX70) with UV illumination (Sherr et al. 1993). For the naked ciliate and tintinnid counts and analyses, $100 \mathrm{ml}$ samples were preserved in $2 \%$ Lugol's iodine solution and kept in a cold room at $4^{\circ} \mathrm{C}$ in the dark until analysis. Naked ciliates and tintinnids were identified, measured and counted with an inverted microscope (Olympus IX70) after a $100 \mathrm{ml}$ sample was left to settle in an Utermöhl chamber for 24 h (Utermöhl 1931).

Mesozooplankton were sampled using subsurface horizontal net tows. AWP2 net type with a mesh size of $80 \mu \mathrm{m}$ and an opening diameter of $50 \mathrm{~cm}$ was used. In general, this plankton net was towed at an average speed of $3 \mathrm{~km} \mathrm{~h}^{-1}$ for 2 to $3 \mathrm{~min}$. The volumes of water filtered by the file averaged 20 to $30 \mathrm{~m}^{3}$ and were calculated precisely for each trawl, taking into account the speed of the boat and the time of immersion of the net. Once the net had been brought back on board, the contents of the collector were sieved over $80 \mu \mathrm{m}$ to concentrate the sample and then transferred to a $250 \mathrm{ml}$ sample bottle fixed with $4 \%$ stabilized formaldehyde. The samples were then stored at room temperature until analysis (diversity and abundance). Abundances of mesozooplankton considered as potential predators and trophic competitors of Crassostrea gigas larvae were estimated using a binocular microscope with taxonomic identification (Rose 1933). The 'trophic competitors' group was determined as the sum of copepod nauplii, annelids and barnacle larvae, ascidia and gastropod larvae. 'Potential predators' were assessed as the sum of cladocerans (Penilia avirostris, Podon spp., and Evadne spp.), decapod larvae, mysids and hydrozoa (Obelia spp.). Mesozooplankton are expressed as individuals per cubic meter.

\section{Data analysis}

All data analyses were performed with R statistical software (R Core Team 2015). Decimal logarithm and square-root transformations were used to tend towards linearity of response variables and to linearize the relationship with explanatory variables (Table 1).

An ANOVA was performed to test the effect of year and sampling site on the recruitment of observed spat abundances with Power Box-Cox transformation (lambda $=-0.63$ ). Normality and heteroscedasticity of residuals were checked by visual inspection. Oyster spat recruitment was graphically described using comparison of means with $95 \%$ confidence intervals.
The relationships between abundances of larvae at different stages (i.e. small, large, pediveliger, postlarvae and newly settled spat) were studied using a series of non-parametric Spearman correlation tests and linear models. In addition, we used the ratio of pediveliger to spat abundance to quantify successful metamorphosis. The Listel sampling site was excluded from the D-larvae analysis because it is located outside the geographic location of shellfish farming, thus inducing very few small larvae supplies.

To study the influence of environmental (hydrological and planktonic) variables on the different life stages, we integrated the data over periods that matched the time scale of the process under study. Hence, to characterize the environment of the pelagic larval and settling phases, we averaged, respectively, the environmental variables over 2 periods: a $22 \mathrm{~d}$ period before retrieval of the collectors (suffix variable LARV for larval phase) and over a $14 \mathrm{~d}$ period preceding retrieval of the collectors to characterize the environment during metamorphosis (suffix variable MET for metamorphosis). Small and large pelagic larvae abundances are represented with their maxima in both the LARV and MET periods.

A decision tree method was used to explore the links between target variables (abundance of pediveliger, abundance of spat and survival after metamorphosis) and environmental variables, with the package 'party' provided by the CRAN-R Project, with conditional inference trees ('ctree') (Hothorn et al. 2006a,b). As only the first splitting path of the decision trees was significant, we split the dataset in 2 and performed simple graphical and statistical tests such as boxplots to observe the quantitative effects of significant variables on the dataset.

A principal component analysis (PCA), based on plankton data with recruitment factor representation, is presented to explore and illustrate interactions between the pediveliger and spat classes. KruskalWallis tests were used to assess significant environmental factors on the classes Pedi-, Pedi+, Spat-, Spat+ and significant favorable or unfavorable parameters of the recruitment windows to identify the optimum recruitment windows.

\section{RESULTS}

Remarkable abundance of Pacific oyster spat were observed each year at each of the 4 sites sampled in the Thau lagoon (Fig. 4). Over the $3 \mathrm{yr}$, we assessed 12 events of medium spat recruitment (21 to 200 ind. plate $^{-1}$ ), 19 events of low recruitment ( 1 to 20 ind. 
Table 1. Variables characterizing the interactions between the environment and Pacific oyster larvae. Each environmental variable was averaged over a $22 \mathrm{~d}$ period preceding retrieval of the collectors and over a 2 wk period preceding the retrieval of the collectors to characterize the environment for metamorphosis

\begin{tabular}{|c|c|c|c|c|}
\hline Variables & Description & Units & Transformation & Abbreviation \\
\hline \multicolumn{5}{|l|}{ Target variables } \\
\hline Oyster spat & Abundance & ind. plate ${ }^{-1}$ & $\begin{array}{c}\log _{10}(x+1) \text { or } \\
\text { power Box-Cox } \\
(\text { lambda }=-0.63)\end{array}$ & $\begin{array}{l}\text { log_spat or } \\
\text { pbc_spat }\end{array}$ \\
\hline Postlarvae & Abundance & ind. plate ${ }^{-1}$ & $\log _{10}(x+1)$ & log_post \\
\hline Pediveligers & Abundance & ind. plate ${ }^{-1}$ & $\log _{10}(x+1)$ & log_pedi \\
\hline \multicolumn{5}{|l|}{ Environmental variables } \\
\hline Max. small larvae & $\begin{array}{l}\text { Maximum small pelagic } \\
\text { larvae abundance }\end{array}$ & ind. $\mathrm{m}^{-3}$ & $\log _{10}(x+1)$ & log_max_SL \\
\hline Max. large larvae & $\begin{array}{c}\text { Maximum large pelagic } \\
\text { larvae abundance }\end{array}$ & ind. $\mathrm{m}^{-3}$ & $\log _{10}(x+1)$ & log_max_LL \\
\hline Pediveliger/spat survival & $\begin{array}{l}\text { Ratio of pediveliger } \\
\text { abundance on oyster spat }\end{array}$ & - & - & - \\
\hline Oxygen concentration & Daily average & $\mathrm{mg} \mathrm{l}^{-1}$ & - & - \\
\hline Temperature & Daily average & ${ }^{\circ} \mathrm{C}$ & - & - \\
\hline Salinity & Daily average & No units & - & - \\
\hline Bacteria & Abundance & $10^{6}$ cells $1^{-1}$ & - & log_bact \\
\hline Total picoeukaryotes & Abundance & $10^{6}$ cells $1^{-1}$ & square $\operatorname{root}(x)$ & sqrt_peuk_tot \\
\hline Total cyanophycae & Abundance & $10^{6}$ cells $1^{-1}$ & square $\operatorname{root}(x)$ & sqrt_cyan \\
\hline Picoeukaryotes + cyanophycae & Abundance & $10^{6}$ cells $1^{-1}$ & $\log _{10}(x+1)$ & log_pico_tot \\
\hline Nanophytoplankton & Abundance & $10^{6}$ cells $1^{-1}$ & $\log _{10}(x+1)$ & log_nano \\
\hline Cryptophycae & Abundance & $10^{6}$ cells $1^{-1}$ & $\log _{10}(x+1)$ & log_crypto \\
\hline Nanophytoplankton + cryptophycae & Abundance & $10^{6}$ cells $1^{-1}$ & $\log _{10}(x+1)$ & log_nano_tot \\
\hline Heterotrophic flagellates & Abundance & cells $1^{-1}$ & $\log _{10}(x+1)$ & log_HF \\
\hline Ciliates & Abundance & cells $1^{-1}$ & $\log _{10}(x+1)$ & log_ciliates \\
\hline Tintinnidae & Abundance & cells $1^{-1}$ & $\log _{10}(x+1)$ & log_tinti \\
\hline Diatom & Abundance & cells $1^{-1}$ & $\log _{10}(x+1)$ & log_diatom \\
\hline Dinoflagellates & Abundance & cells $1^{-1}$ & $\log _{10}(x+1)$ & log_dinoflagellates \\
\hline Chaetoceros spp. & Abundance & cells $1^{-1}$ & $\log _{10}(x+1)$ & log_chaetoceros \\
\hline Total chlorophyll a & Biomass & $\mu \mathrm{g} \mathrm{chl} \mathrm{a} \mathrm{l^{-1 }}$ & - & total_chloa \\
\hline Picophytoplankton & Biomass & $\mu \mathrm{g} \mathrm{chl} \mathrm{a} \mathrm{l}^{-1}$ & - & pico \\
\hline Nanophytoplankton & Biomass & $\mu g \operatorname{chl} a \mathrm{l}^{-1}$ & - & nano_3_20 \\
\hline Picophytoplankton + nanophytoplankton & Biomass & $\mu g$ chl a $\mathrm{l}^{-1}$ & - & nano_low20 \\
\hline Microphytoplankton $>20 \mu \mathrm{m}$ & Biomass & $\mu g l^{-1}$ & - & micro \\
\hline Competitors & Abundance & ind. $\mathrm{m}^{-3}$ & $\log _{10}(x+1)$ & $\log \_$comp \\
\hline Predators & Abundance & ind. $\mathrm{m}^{-3}$ & $\log _{10}(x+1)$ & log_pred \\
\hline
\end{tabular}

plate $^{-1}$ ) and 65 events of null recruitment. The analysis was performed using the whole dataset over the 3 yr period but spat abundances did not differ significantly among years (Table 2). In contrast, the site factor had a significant effect on oyster spat abundances (pbc_spat, lambda $=-0.63, \mathrm{p}<0.05$ ) (Table 2).

In 2012, 2 medium intensity spatfall events occurred, the first in mid-August, with 126 and 47 ind. plate $^{-1}$ at the Listel and Bouzigues sites, respectively, and the second at the end of September with 45 and 21 ind. plate ${ }^{-1}$ at the Bouzigues and Listel sites, respectively (Fig. 4). In 2013, there was a single medi- um spatfall event lasting from the middle to the end of August at all 4 sites, with maximum values of 188 , 187, 91 and 49 ind. plate ${ }^{-1}$ at Bouzigues, Marseillan, Listel and Meze, respectively. In 2014, a medium spatfall event occurred at Listel only, but lasted longer, from the end of August to the end of September. To summarize, medium spatfall events were observed each year at Listel, in 2 yr at Bouzigues and only in $1 \mathrm{yr}$ at Marseillan and Meze. It is interesting to note that medium spat recruitment occurred any time from August to September, but never in July or October. 


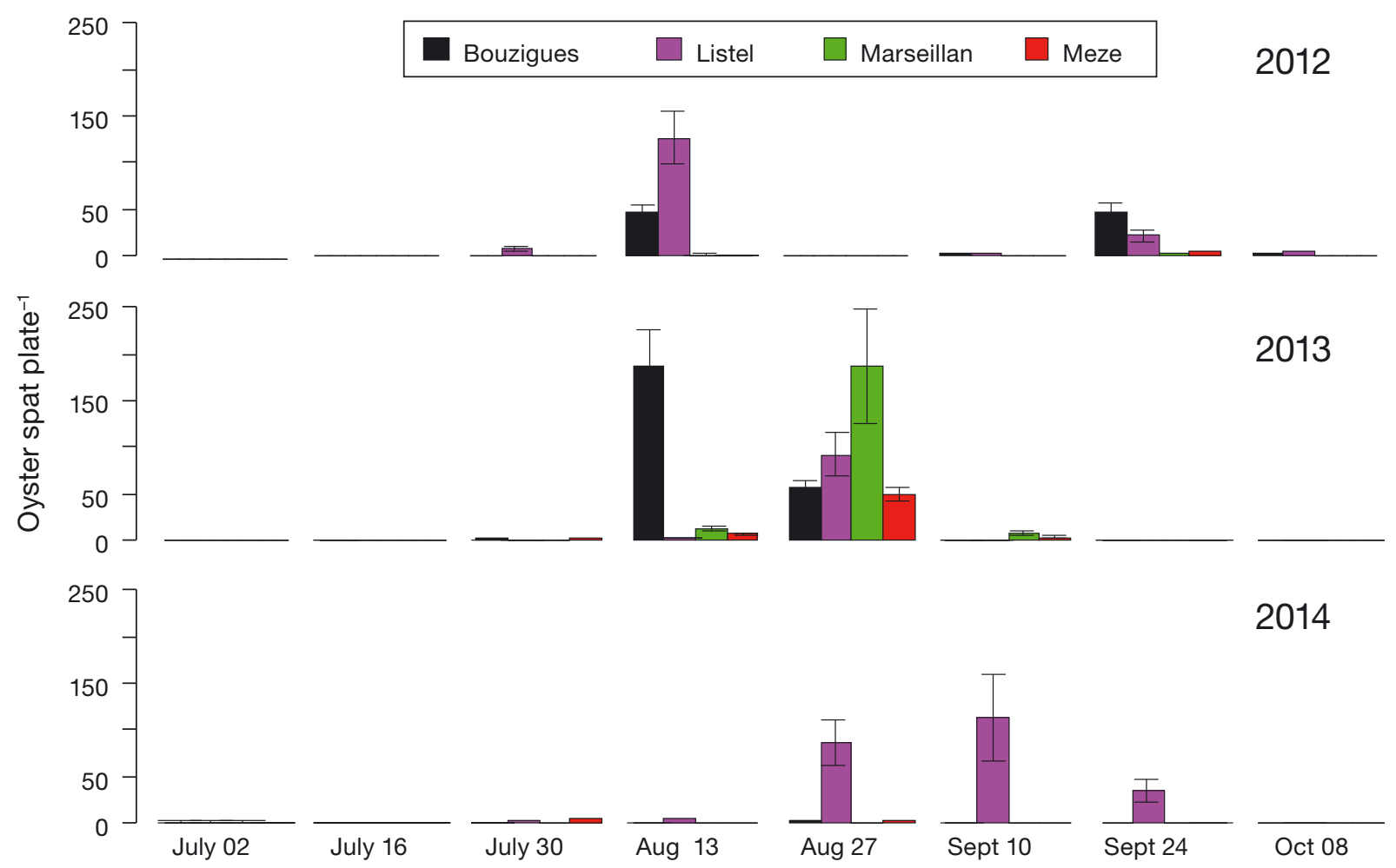

Fig. 4. Mean $( \pm 95 \%$ CI) Pacific oyster spat abundance per plate observed at the 4 spatfall sampling sites (Bouzigues, Listel, Marseillan and Meze) at 2 wk intervals throughout the summer $(2012,2013,2014)$. Spat abundances were estimated after 4 wk of immersion ( $\mathrm{n}=54$ per date and sampling site)

Table 2. ANOVA examining the effect year and site factors on Pacific oyster spat abundance per plate (power Box-Cox transformation; lambda $=-0.63, \mathrm{n}=96)$. Significant values in bold $(\mathrm{p}<0.05)$

\begin{tabular}{|lccccc|}
\hline & df & SS & MS & $F$ & $\operatorname{Pr}(>\mathrm{F})$ \\
\hline Site & 3 & 2.528 & 0.8425 & 3.353 & $\mathbf{0 . 0 2 2 7}$ \\
Year & 2 & 0.080 & 0.0400 & 0.159 & 0.8529 \\
Site $\times$ year & 6 & 3.210 & 0.5351 & 2.130 & 0.0582 \\
Residuals & 84 & 21.105 & 0.2512 & & \\
\hline
\end{tabular}

Significant correlations were found between the abundance of small D-larvae and the abundance of pediveligers, specifically in the shellfish-farmed area (Fig. $5 \mathrm{a} ; \mathrm{n}=75, \rho=0.44, \mathrm{p}<0.001$ ). At the lagoon scale, a significant correlation was found between large larvae and pediveligers (Fig. $5 \mathrm{~b} ; \mathrm{n}=100, \rho=$ $0.45, \mathrm{p}<0.001)$. The relationship between large larvae and pediveliger abundance, assessed using a linear model, was strong (log_pedi $=0.864$ log_max_LL).

Pediveliger and postlarvae abundances were on average significantly correlated (Fig. $5 \mathrm{c} ; \mathrm{n}=100, \rho=$ $0.47, \mathrm{R}^{2}=31 \%, \mathrm{p}<0.001$ ) and the relationship between pediveligers and postlarvae (log_postlarvae $=$ 0.41 log_pedi) was successful or ranged from low to zero (failure of metamorphosis). Among 69 harvest events with less than 2 spats (Spat-), 26 (38\%) had a relatively high number of pediveligers $2 \mathrm{wk}$ before ( $>20$ ind. plate ${ }^{-1}$, i.e. Pedi+) whereas $43(62 \%)$ did not $\left(<20\right.$ ind. plate ${ }^{-1}$, i.e. Pedi-).

Oyster spat abundances were highly correlated with postlarvae abundances (Fig. $5 d_{i} n=96, \rho=0.69$, $\left.\mathrm{R}^{2}=65 \%, \mathrm{p}<0.001\right)$. The linear model between postlarvae and oyster spat was, on average, defined as $\log \_s p a t=0.59$ log_post_larvae.

Concerning environmental drivers and based on preliminary analyses of the decision trees, we found that (1) spat abundance was significantly higher $(\mathrm{p}=$ 0.034) when the temperature (throughout the larval pelagic period; LARV) was above $26.5^{\circ} \mathrm{C}$ (Fig. 6a); (2) the abundance of pediveligers was significantly higher $(p=0.012)$ above a threshold value of Chaetoceros abundance $\left(\sim 345 \times 10^{3}\right.$ cells l$^{-1}$; Fig. 6 b) during the larval cycle; and (3) the success of metamorphosis survival was significantly higher $(p=0.014)$ with high nanophytoplankton biomass (throughout the

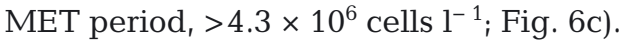

A PCA of the environmental dataset with the recruitment factor (categorized as Pedi-, Pedi-Spatand Pedi+Spat+) showed that the 2 first axes ex- 

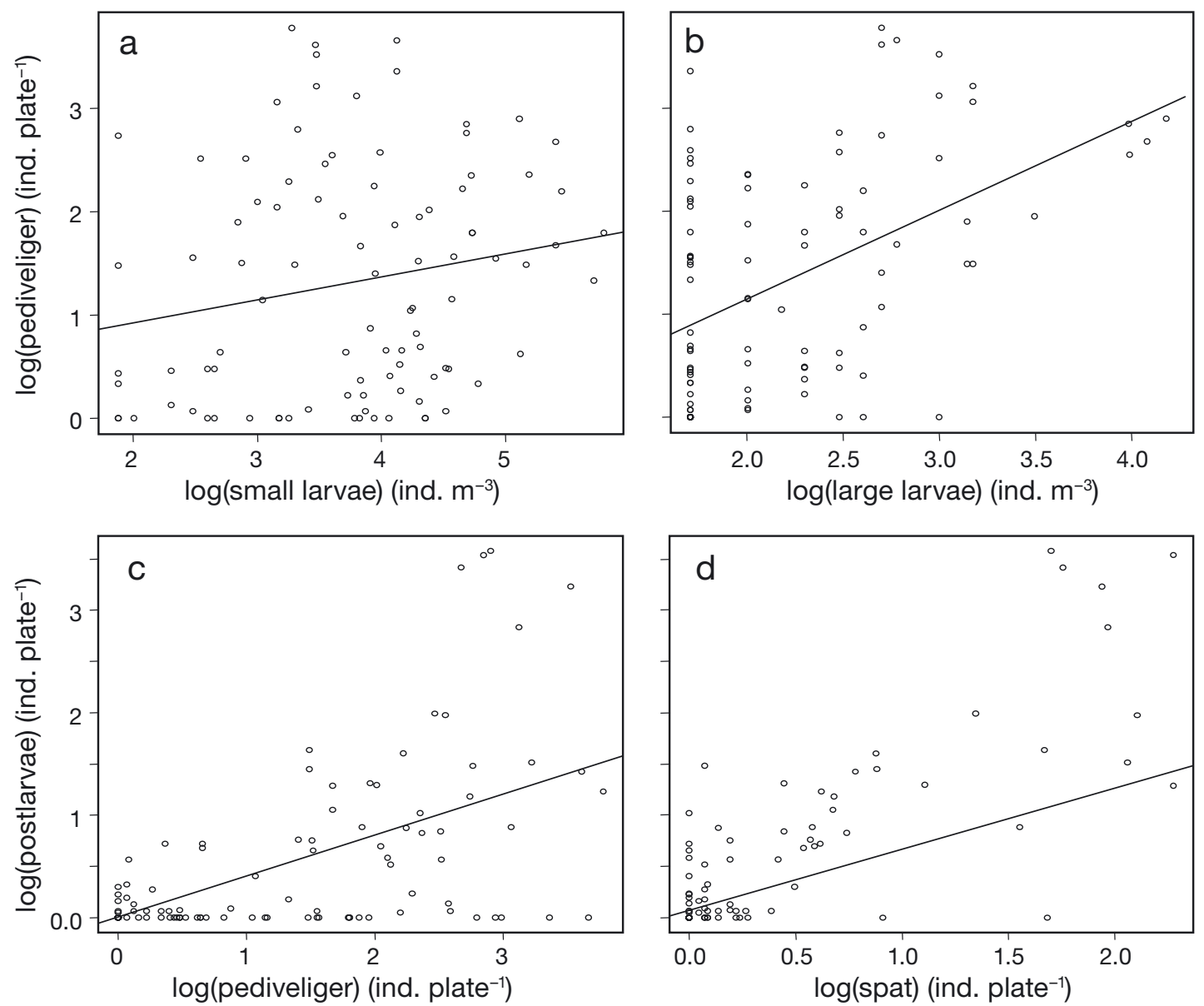

Fig. 5. Relationships between Pacific oyster pediveliger and (a) small larvae, (b) large larvae and postlarvae and (c) pediveliger or (d) spat abundances for the years 2012, 2013 and 2014

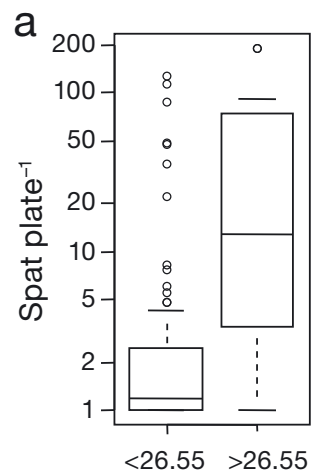

Temperature_LARV

$\left({ }^{\circ} \mathrm{C}\right)$ b

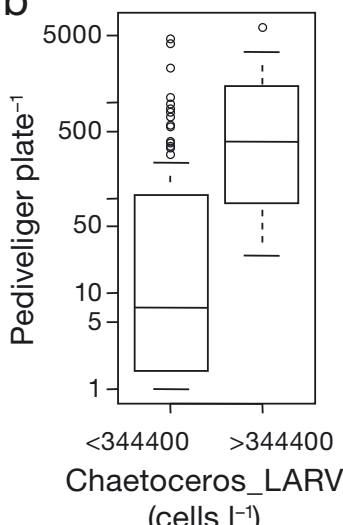

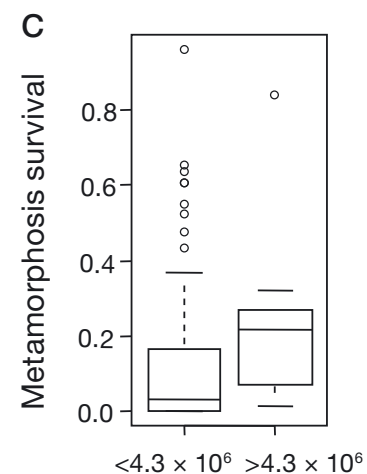

Nanophytoplankton_MET (cells $\mathrm{I}^{-1}$ )
Fig. 6. Environmental and planktonic variables that have a significant effect on pre- and post-settled stages of Pacific oyster: (a) temperature averaged over the larval period (Temperature_LARV) on spat abundance; (b) Chaetoceros abundance averaged over the larval period (Chaetoceros_LARV) on the abundance of pediveligers; and (c) nanophytoplankton abundance averaged over the metamorphosis period (Nanophytoplankton_MET) on metamorphosis survival. Mid-line: median; box: $25^{\text {th }}$ and $75^{\text {th }}$ percentiles; whiskers: $1.5 \times$ the interquartile range; circles: outliers. plained $49.4 \%$ of the total variance of our dataset (Fig. 7). The first axis was built with the contributions of nanophytoplankton biomass (nano_low20 ${ }^{\mathrm{B}}$, nano_3_20 ${ }^{\mathrm{B}}$ ) and abundances ( $\log _{-}$ nano $\left.^{\mathrm{A}}, \log _{\text {nnanotot }} \mathrm{A}\right)$ and total_chloa biomass (total_chloa ${ }^{B}$ ). This first axis can be seen as a temporal gradient representative of fauna, flora and hydrological successions (Fig. 7). The second axis separated picophytoplankton abundance (sqrt_peuk_tot ${ }^{\mathrm{A}}$, log_pico ${ }^{\mathrm{A}}$ ), biomass $\left(\right.$ pico $^{\mathrm{B}}$ ) and cryptophyte abundance (log_crypto ${ }^{\mathrm{A}}$ ) from microphytoplankton $>20 \mu \mathrm{m}$ biomass (micro $^{\mathrm{B}}$ ) and Chaetoceros abundance (log_ chaetoceros $^{\mathrm{A}}$ ). On this axis, ciliate and dinoflagellate abundances are also opposed to picoeukaryote abundances, heterotrophic flagellate abundance 

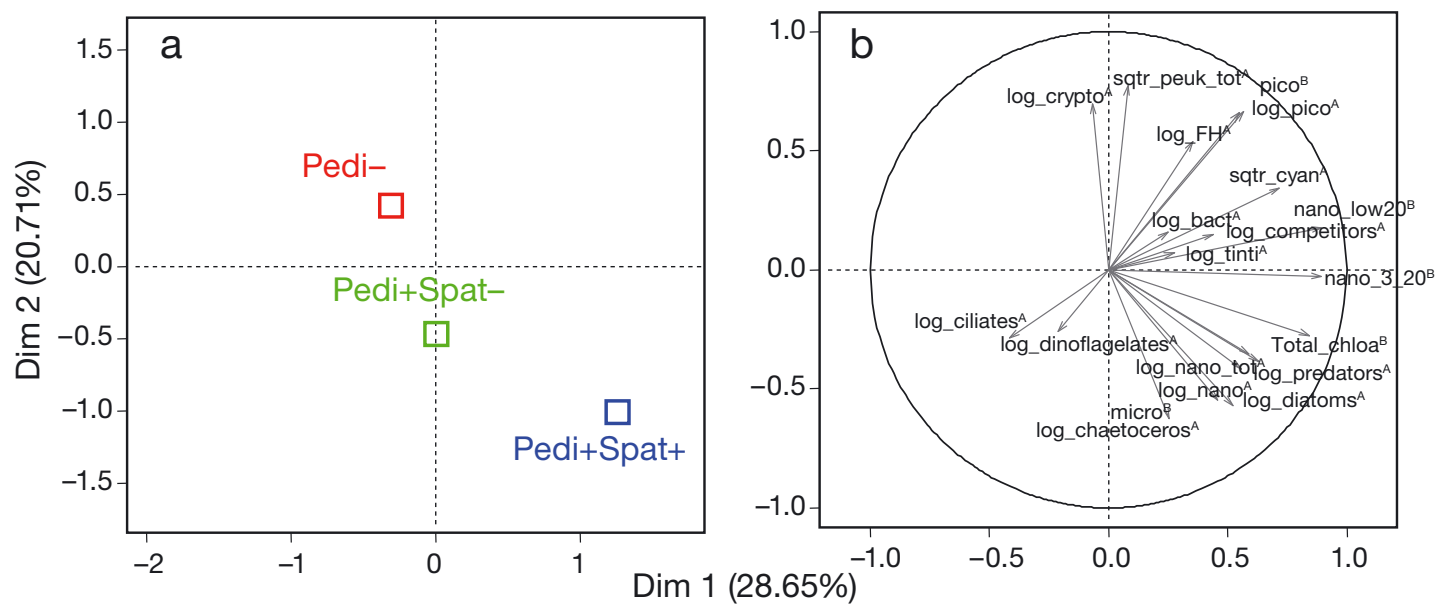

Fig. 7. Principal component analysis plots of (a) recruitment factors and (b) correlation circle of environmental transformed data integrated over a 22 d period before retrieval of the collector (superscript A: abundance; B: biomass). Recruitment factor categorizes Pacific oyster pediveliger and spat abundances 'Pedi-' and 'Spat-' by aggregating the abundances from 0 to 20 ind. plate ${ }^{-1}$, and 'Pedi+' and 'Spat+' by aggregating abundances with $>20$ ind. plate ${ }^{-1}$
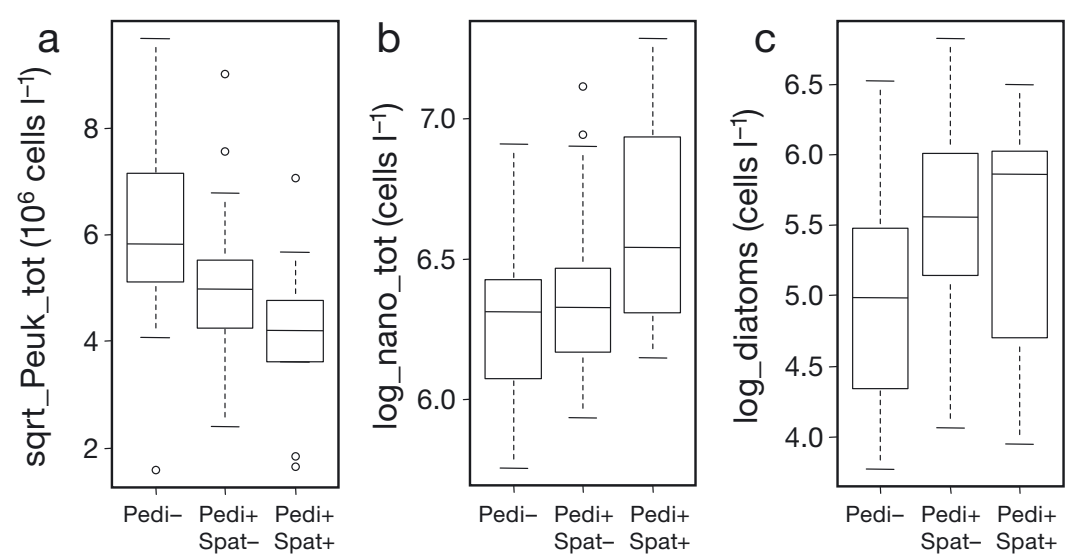

dance (Fig. 7b). The success of metamorphosis (i.e. the Spat- and Spat+ terms) was mostly differentiated on the first axis, with positive effects of nanophytoplankton biomass.

Non-parametric analyses (KruskalWallis test) of the whole dataset distinguished 7 variables with significant effects on recruitment $(p<0.05)$. All 7 variables were integrated over the 3 wk pelagic larval phase (i.e. LARV).

High pediveliger abundance and/or successful metamorphosis were observed when picoeukaryote abun-

Fig. 8. Plankton variables that had a significant effect on Pacific oyster recruitment. The values on the $y$-axis are (a) the square root values of total picoeukaryote abundance and $(b, c) \log _{10}$ values of total nanophytoplankton and diatom abundances $\left(\mathrm{n}_{\text {Pedi- }}=37, \mathrm{n}_{\text {Pedi+Spat- }}=26\right.$ and $\left.\mathrm{n}_{\text {Pedi+Spat+ }}=9\right)$, respectively. Mid-line: median; box: $25^{\text {th }}$ and $75^{\text {th }}$ percentiles; whiskers: $1.5 \times$ the interquartile range; circles: outliers. See Fig. 7 and Table 1 for definitions

dance was low (Fig. 8a), or when total nanophytoplankton levels (Fig. 8b) or diatom levels (Fig. 8c) were high. A total of $79 \%$ percent of the variability of diatom abundances $(p<0.001)$ was explained by Chaetoceros abundances.

and picophytoplankton biomass. Their contribution to the building of the axis was, however, low. The second axis can be seen as a spatial gradient reflecting the effect of lagoon confinement and the effect of the shellfish biocoenosis on hydrobiology.

The barycenters of our recruitment factor (Pedi-, Pedi-Spat-, Pedi+Spat+) occurrences are well differentiated on the first PCA axis (Fig. 7a). Pediveliger abundance (Pedi-, Pedi+) was mostly correlated with the second axis, with positive effects of Chaetoceros abundance, microphytoplankton and nanophytoplankton, and negative effects of picophytoplankton (abundance and biomass) and cryptophyte abun-
The effect of microphytoplankton abundance on recruitment (data not shown) was similar to the effect of diatoms.

Concerning hydrological variables, we found no effect on pediveliger supply but a significant effect of oxygen concentrations and temperature on recruitment, with more Pedi+Spat+ occurrence at lower oxygen concentrations (Fig. 9a) and higher temperatures (Fig. 9b).

The changes in recruitment over time (aggregated over the 3 sampling years) in each of the 3 recruitment categories (Pedi-, Pedi-Spat+, Pedi+Spat+) defined above suggested a strong summer pattern independ- 

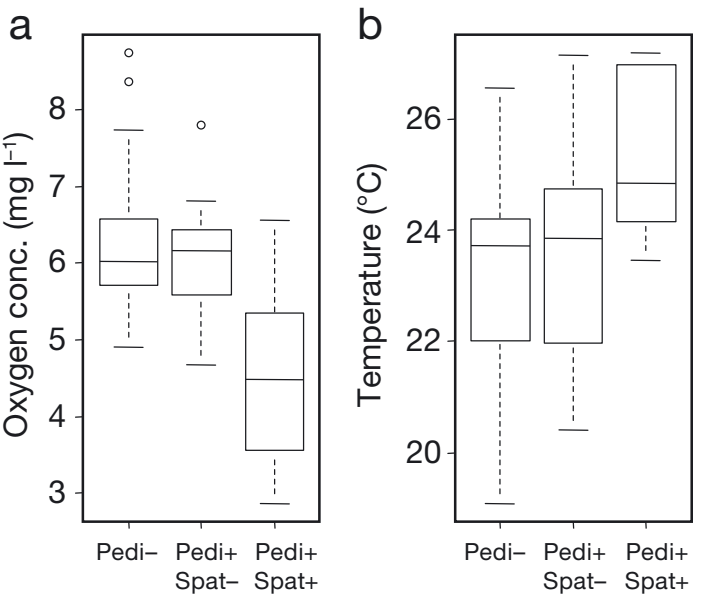

Fig. 9. Environmental variables that had a significant effect on Pacific oyster recruitment according to oxygen concentration $\left(\mathrm{n}_{\text {Pedi-Spat- }}=27, \mathrm{n}_{\text {Pedi-Spat }}=18, \mathrm{n}_{\text {Pedi }+ \text { Spat }+}=6\right)$ and temperature $\left(\mathrm{n}_{\text {Pedi-Spat- }}=46, \mathrm{n}_{\text {Pedi-Spat+ }}=38, \mathrm{n}_{\text {Pedi+Spat }}=12\right)$. See Figs. $7 \& 8$ for definitions

ent of the year (Table 3): no Pedi+Spat+ occurrences were observed in Weeks 24 to 29 (June and July) whereas Weeks 31 to 37 (August and September) saw the occurrence of Pedi+Spat+. Conditions were unfavorable at the end of the season (after Week 38), with no Pedi+Spat+ occurrence.

Kruskal-Wallis tests based on these new categories (favorable vs. unfavorable windows) revealed a significant difference $(\mathrm{p}<0.05)$ for 13 of the 46 environmental variables: the 3 hydrological variables (temperature, oxygen and salinity) and the 10 transformed planktonic variables. Temporal windows that favor recruitment are associated with lower oxygen concentrations, higher temperatures and higher salinity, higher total_chloa, pico- and nanophytoplankton biomass, higher abundances of heterotrophic flagellates and trophic competitors, and lower abundances of ciliates and dinoflagellates (Fig. 10). The effects of unfavorable or favorable windows were similar for picocyanobacteria, picoeukaryote and picophytoplankton abundances. Only picophytoplankton results are presented here.
In unfavorable periods, ciliates were mainly represented by higher abundances of naked ciliates like Scuticociliates (1100 cells $~^{-1}$ including Uronematidae, Philasteridae, Balanion), Laboea spp., Favella erhenbergii and tintinnid ciliates like Eutintinus spp. and Tintinnopsis spp. In the same period, dinoflagellates were represented by non-toxic species such as Gyrodinium spirale and Prorocentrum micans (both

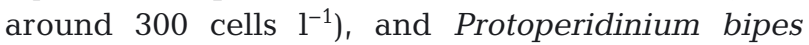
(around 40 cells $^{-1}$ ).

\section{DISCUSSION}

Our general objective was to study recruitment of the Pacific oyster Crassostrea gigas by monitoring the different larval stages and exploring the effects of lagoon environmental conditions on successful larval development and recruitment. The present study showed that there was no statistical difference in spat abundance at an inter-annual scale, but there was strong temporal variability at an intra-annual scale, with clear favorable versus unfavorable windows. The unfavorable windows (June and July) showed good supplies of larvae ( $>20$ ind. plate ${ }^{-1}$ ) but metamorphosis failure, suggesting a possible biological obstacle at this step. Early summer months are usually characterized by rising temperatures, and increasing metabolism of poikilotherm filter feeders. Consequently, only small quantities of nano- and microplankton are available during that period since nano- and microplankton are mainly consumed by filter feeders (Dupuy et al. 2000). Indeed, the unfavorable recruitment windows in early summer were characterized by low pico-, nano- and microphytoplankton biomass. We therefore suggest that a topdown control of primary production by filter feeders explains the observed unfavorable recruitment period in Thau lagoon.

Picoplankton also support grazing by ciliate and flagellate protists (Lam-Hoai et al. 1997, Bec et al.

Table 3. Evolution of changes in recruitment categories over time. Recruitment factor categorizes Pacific oyster pediveliger and spat abundances Pedi- and Spat- by aggregating the abundances from 0 to 20 ind. plate ${ }^{-1}$, and Pedi+ and Spat+ by aggregating the abundances with $>20$ ind. plate ${ }^{-1}$. See Fig. 7 for definitions

\begin{tabular}{|c|c|c|c|c|c|c|c|c|c|c|c|c|c|c|c|c|c|}
\hline \multirow{2}{*}{\multicolumn{2}{|c|}{$\begin{array}{l}\text { Months } \\
\text { Weeks }\end{array}$}} & \multicolumn{2}{|c|}{ June } & \multicolumn{4}{|c|}{ July } & \multicolumn{5}{|c|}{ August } & \multicolumn{4}{|c|}{ September } & \multirow{2}{*}{$\begin{array}{c}\text { October } \\
41\end{array}$} \\
\hline & & 24 & 26 & 27 & 28 & 29 & 30 & 31 & 32 & 33 & 34 & 35 & 36 & 37 & 38 & 39 & \\
\hline \multirow[t]{3}{*}{ Recruitment factor } & Pedi- & 4 & 4 & 0 & 4 & 0 & 3 & 2 & 2 & 3 & 5 & 3 & 7 & 0 & 5 & 1 & 3 \\
\hline & Pedi+Spat- & 4 & 4 & 4 & 4 & 4 & 4 & 0 & 1 & 1 & 2 & 1 & 0 & 2 & 3 & 3 & 1 \\
\hline & Pedi+Spat+ & 0 & 0 & 0 & 0 & 0 & 1 & 2 & 5 & 0 & 1 & 0 & 1 & 2 & 0 & 0 & 0 \\
\hline \multicolumn{2}{|c|}{ Recruitment windows } & \multicolumn{5}{|c|}{ Unfavorable } & \multicolumn{6}{|c|}{ Favorable } & & & \multicolumn{3}{|c|}{ Unfavorable } \\
\hline
\end{tabular}


[O2] $\left(\mathrm{mg} \mathrm{l}^{-1}\right)$

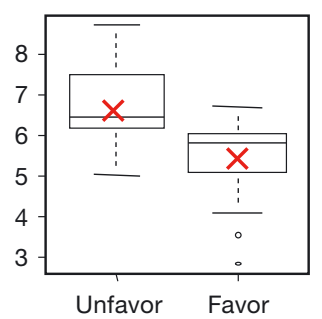

Total_chloa

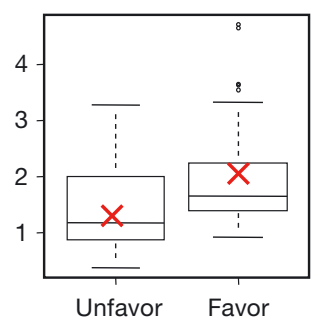

Pico tot abund.

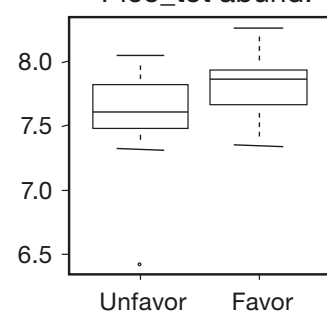

Temp. $\left({ }^{\circ} \mathrm{C}\right)$

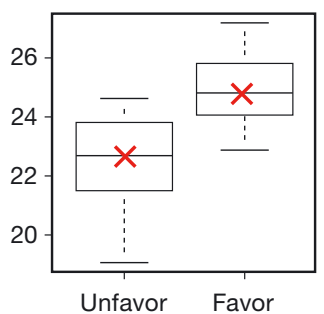

Picophytoplankton

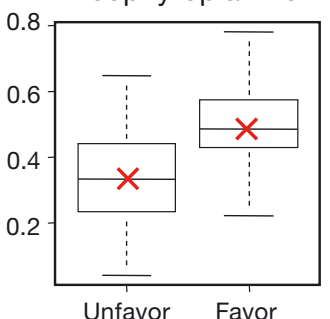

Ciliates abund

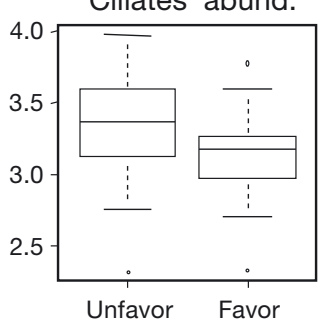

Salinity

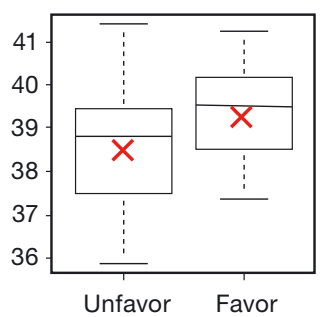

Nanophytoplankton

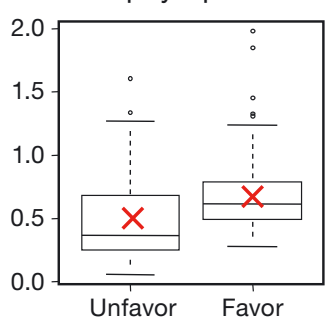

Fig. 10. Environmental and planktonic abundances that showed a significant difference $(\mathrm{p}<0.05)$ in favorable $(\mathrm{n}=36)$ vs. unfavorable $(\mathrm{n}=36)$ temporal recruitment windows for $\mathrm{Pa}$ cific oyster. Total_chloa, pico- and nanophytoplankton are biomass expressed in $\mu \mathrm{g} \mathrm{chl} \mathrm{a} \mathrm{l}^{-1}$; pico_tot (picoeukaryotes+cyanophycae) abundance is in $10^{6}$ cells $^{-1}$; ciliates, heterotrophic flagellates and dinoflagellates in $\log _{10}$ cells $1^{-1}$; competitors in $\log _{10}$ ind. $\mathrm{m}^{-3}$. Mid-line: median; box: $25^{\text {th }}$ and $75^{\text {th }}$ percentiles, whiskers: $1.5 x$ the interquartile range; circles: outliers; red crosses: means

Heterotrop. flagel. abund.

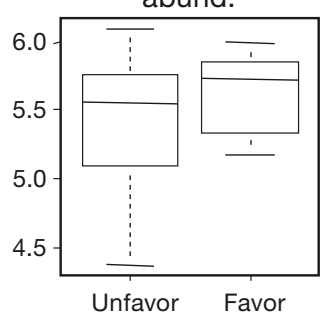

Dinoflagellates abund.

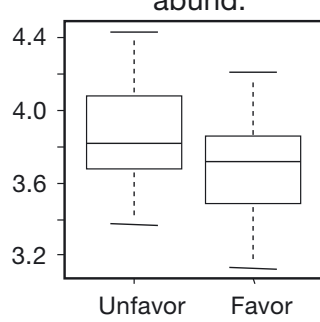

Competitors abund.

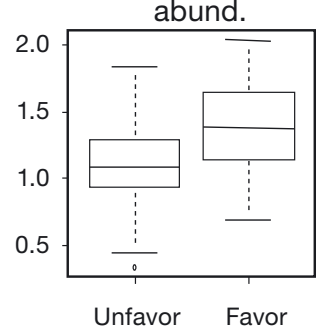

2005). A few authors have reported a negative impact of ciliates on the development of mollusk bivalve spat (inhibition of settlement) (Plunket \& Hidu 1978, Elston et al. 1999, Shimeta et al. 2012). Our results support this hypothesis since a negative correlation was observed between the abundance of ciliates and the metamorphosis success of $C$. gigas.

Dinoflagellate and diatom population dynamics are known to be asynchronous in lagoons with respect to nutrient inputs (Collos et al. 2008). In the present study, the unfavorable recruitment window was characterized by high abundances of mixotrophic dinoflagellates during the favorable period even though summer is not the best ecological window for dinoflagellates (Collos et al. 2008). We suggest that high concentrations of chemical contaminants, such as herbicides used in antifouling boat paints or in agriculture, favor these mixotrophic and heterotrophic organisms. Dinoflagellates are part of the diet of oysters (both adults and spat; Baldwin 1991, Baldwin \& Newell 1995), but can inhibit the larval development and recruitment of bivalve mollusks (Mu \& Li 2013, Mizuno et al. 2015).
The unfavorable recruitment window preceded a favorable window that systematically lasted from late July to early September. This favorable window was characterized by the availability of trophic variables for oyster larvae such as the abundance of nanophytoplankton and Chaetoceros spp. Larval food sources of Crassostrea spp. in the natural environment are multiple (types and particle sizes), and their consumption varies with larval stages: bacteria, phytoplankton, particulate and dissolved organic matter and protozoa (Douillet 1993, Raby et al. 1997, Sommer et al. 2000). At the beginning of August, warmer conditions (temperature $>25^{\circ} \mathrm{C}$ ) could cause a shift in the regeneration of organic matter and in remineralization favoring fast growing diatoms (Collos et al. 2003), most of which are Chaetoceros spp. (Collos 1986, Collos et al. 1997). As a result, the concentrations of nano- and microphytoplankton including diatoms are high and favor successful C. gigas recruitment with (this time) a bottom-up control of phytoplankton on larvae. The relationship between various pelagic cues and the improvement of benthic invertebrate recruitment is well known (Miron et al. 
1995, Pineda et al. 2010). Particularly, the 'trophic settlement trigger' concept could indirectly affect recruitment by strongly improving the settlement rate of pediveliger larvae (Toupoint et al. 2012a,b). In addition to the match/mismatch theory (Cushing 1990), this concept shows the benefit of pelagic cues in favor of settlement success. Without augured benefit for Chaetoceros on pelagic larval development, our results appear to support the trophic settlement trigger hypothesis induced with the significant relationship between this diatom genus and C. gigas pediveliger abundance.

Our results showed extreme spatial heterogeneity of oyster spat collection among the sampling sites. The ecological conditions within the Thau lagoon are known to be highly contrasted (Troussellier \& DeslousPaoli 2001) and the spatial organization of oyster recruitment will consequently need to be studied more precisely. First, the exchange of water with the open sea and the circulation of water within the lagoon (Guelorget et al. 1994, Lam-Hoai et al. 1997) define the habitat and its ecological niches depending on the proportion of marine and lagoon water volumes (Fiandrino et al. 2017). In addition, the variability of the plankton communities in space and over time is significantly influenced by the hydrodynamic conditions, which in turn, depend on the wind (Millet \& Cecchi 1992, Troussellier et al. 1993). Hydrodynamic circulation patterns are also one of the main factors that influence larval dispersal and spat distribution (North et al. 2008, Hubbard \& Reidenbach 2015, Larsson et al. 2016). The use of hydrodynamic models, such as the Mars 3D model (Lazure \& Dumas 2008, Fiandrino et al. 2017) would prove useful to quantify larval dispersal and connectivity once adapted for lagoon ecosystems in semi-closed nanotidal regimes. On the other hand, intensive shellfish-farmed communities structure the interactions between species and the supply of mollusk larvae (Borsa \& Millet 1992). The Pacific oyster is an ecosystem engineer and keystone species, and has a significant impact on its own ecosystem, particularly at a high density in an enclosed system (Mazouni et al. 1998, Souchu et al. 2001, Bec et al. 2005). Significant chl $a$ and particulate organic carbon depletion were measured in the shellfish farming zone (Souchu et al. 2001) along with a reduction in microzooplankton biomass compared with that in the middle of the lagoon (Lam-Hoai et al. 1997). Oyster larvae take place in the microzooplankton compartment and a full study of the effect of the breeding zone on the structure of oyster recruitment is now needed after this first ecological approach.
Mass mortalities in oyster juveniles have raised concerns about cultivation practices in Mediterranean lagoons, as the Thau basin depends on supplies of wild oyster juveniles from the Atlantic and individuals raised in French hatcheries. Thus it is important to increase knowledge of local reproduction and native oyster recruitment. Ubertini et al. (2017) showed that the reproduction window stretches from the beginning of June to the end of September. For these authors, phytoplankton concentrations and assemblages affected gametogenesis, with diatoms having a positive effect. No spawning events were observed below $22^{\circ} \mathrm{C}$. The temperature of $23^{\circ} \mathrm{C}$ appears to be a temperature threshold for the occurrence of significant spawning events. Ubertini et al. (2017) also showed that the full and dark moon in combination with high temperature may enhance spawning events. In our 3 yr study (2012 to 2014), we observed natural recruitment of $C$. gigas for the first time in the Mediterranean Thau lagoon. When recruitment occurred, spat collection levels in the Thau lagoon were comparable with those in other French traditional breeding basins (Lagarde et al. 2015a), with recruitment classified from low (up to 20 ind. plate $^{-1}$ ) to medium (up to 200 ind. plate ${ }^{-1}$ ) according to the classification proposed by the French oyster larvae monitoring network in the VELYGER project (Pouvreau et al. 2013, 2016). The discovery of spatproducing areas at a sampling site outside a shellfish-farming area is an important breakthrough and means that spat collection in Mediterranean lagoons may be possible in future (Lagarde et al. 2015b). Indeed, until now, attempts to collect spat have been restricted to shellfish-farming zones in the Thau lagoon, but amounts were too low to be profitable. Further technical experiments are necessary at an industrial scale to improve this novel shellfish-farming practice. There may also be other benefits in using native oysters; they may, for instance, have a better resistance to OsHv1- $\mu$ var (Petton et al. 2015). The use of native oysters may also be considered a more eco-friendly practice for spat supply.

Coastal lagoons are particularly sensitive to nutrient input of anthropogenic origin (Knoppers 1994, Cloern 2001, Kennish \& Paerl 2010) due to restricted exchanges with the sea and intrinsic hydrodynamic patterns (Boesch 2002, Glibert et al. 2011). In French Mediterranean lagoons, anthropogenic nutrient inputs have been reduced, leading to oligotrophication (Leruste et al. 2016). Some authors suggest that the combination of global warming and reduced nutrient loads will reduce phytoplankton biomass, which would benefit picocyanobacteria (Collos et al. 2009). 
In the Thau lagoon, the expected shift in the ecological community structure would presumably change the newly defined optimum recruitment window for the Pacific oyster. Results from the present study show that recruitment success or failure in this Mediterranean lagoon is related to the nursery function of summer biocoenosis trajectories of the lagoon. Further studies are necessary to define the in situ tolerance limits of $C$. gigas, in a strongly fluctuating ecosystem, at the frontiers of its ecological niche.

Acknowledgements. The authors thank the funders of the project 'PRONAMED 2': France-Agrimer, Conseil Régional d'Occitanie/Languedoc-Roussillon, Conseil départemental de l'Hérault, Comité Régional de la Conchyliculture en Méditerranée, Cepralmar and Ifremer. F.L. thanks the RECHAGLO international research group, co-funded by Ifremer and MPO, for encouragement, support and exchanges with Canada. Our special thanks to Adeline Perignon, Erika Gervasoni, Hélène Cochet and Cochet-Environnement, Jean-Louis Guillou, Patrik Le Gall, Gregory Messiaen, Slem Meddah, Solen Soriano and Axel Leurion for their assistance, involvement and commitment during field and laboratory work.

\section{LITERATURE CITED}

Arakawa KY (1990) Natural spat collecting in the Pacific oyster Crassostrea gigas (Thunberg). Mar Behav Physiol 17:95-128

Arnold SN, Steneck RS (2011) Settling into an increasingly hostile world: the rapidly closing 'recruitment window' for corals. PLOS ONE 6:e28681

Baldwin BS (1991) Ingestion of natural plankton by oyster larvae: the relative importance of different cell size fractions. Am Zool 31:55

Baldwin BS, Newell RI (1995) Feeding rate responses of oyster larvae (Crassostrea virginica) to seston quantity and composition. J Exp Mar Biol Ecol 189:77-91

Bec B, Husseini-Ratrema J, Collos Y, Souchu P, Vaquer A (2005) Phytoplankton seasonal dynamics in a Mediterranean coastal lagoon: emphasis on the picoeukaryote community. J Plankton Res 27:881-894

Bec B, Collos Y, Souchu P, Vaquer A and others (2011) Distribution of picophytoplankton and nanophytoplankton along an anthropogenic eutrophication gradient in French Mediterranean coastal lagoons. Aquat Microb Ecol 63:29-45

Ben Kheder R, Quéré C, Moal J, Robert R (2010) Effect of nutrition on Crassostrea gigas larval development and the evolution of physiological indices. Part A: Quantitative and qualitative diet effects. Aquaculture 305: 165-173

Bernard I, Massabuau JC, Ciret P, Sow M, Sottolichio A, Pouvreau S, Tran D (2016) In situ spawning in a marine broadcast spawner, the Pacific oyster Crassostrea gigas: timing and environmental triggers. Limnol Oceanogr 61: 635-647

Bishop CD, Erezyilmaz DF, Flatt T, Georgiou CD and others (2006) What is metamorphosis? Integr Comp Biol 46: 655-661
Blanchard M, Pechenik J, Giudicelli E, Connan JP, Robert R (2008) Competition for food in the larvae of two marine molluscs, Crepidula fornicata and Crassostrea gigas. Aquat Living Resour 21:197-205

*Boesch DF (2002) Challenges and opportunities for science in reducing nutrient over-enrichment of coastal ecosystems. Estuaries 25:886-900

* Borsa P, Millet B (1992) Recruitment of the clam Ruditapes decussatus in the lagoon of Thau, Mediterranean. Estuar Coast Shelf Sci 35:289-300

Bouvy M, Got P, Domaizon I, Pagano M and others (2016) Plankton communities in the five Iles Eparses (Western Indian Ocean) considered to be pristine ecosystems. Acta Oecol 72:9-20

* Buestel D, Ropert M, Prou J, Goulletquer P (2009) History, status and future of oyster culture in France. J Shellfish Res 28:813-820

Bullock JM, Aronson J, Newton AC, Pywell RF, Rey-Benayas JM (2011) Restoration of ecosystem services and biodiversity: conflicts and opportunities. Trends Ecol Evol 26: 541-549

* Cannuel R, Beninger PG (2007) Acquisition of particle processing capability in juvenile oyster Crassostrea gigas: ontogeny of gill mucocytes. Mar Biol 151:897-905

* Cannuel R, Beninger PG, McCombie H, Boudry P (2009) Gill development and its functional and evolutionary implications in the blue mussel Mytilus edulis (Bivalvia: Mytilidae). Biol Bull 217:173-188

Cloern JE (2001) Our evolving conceptual model of the coastal eutrophication problem. Mar Ecol Prog Ser 210: $223-253$

* Collos Y (1986) Time-lag algal growth dynamics: biological constraints on primary production in aquatic environments. Mar Ecol Prog Ser 33:193-206

Collos Y, Vaquer A, Bibent B, Slawyk G, Garcia N, Souchu P (1997) Variability in nitrate uptake kinetics of phytoplankton communities in a Mediterranean coastal lagoon. Estuar Coast Shelf Sci 44:369-375

* Collos Y, Vaquer A, Bibent B, Souchu P, Slawyk G, Garcia N (2003) Response of coastal phytoplankton to ammonium and nitrate pulses: seasonal variations of nitrogen uptake and regeneration. Aquat Ecol 37:227-236

Collos Y, Bec B, Jauzein C, Abadie E and others (2009) Oligotrophication and emergence of picocyanobacteria and a toxic dinoflagellate in Thau lagoon, southern France. J Sea Res 61:68-75

Coon SL, Fitt WK, Bonar DB (1990) Competence and delay of metamorphosis in the Pacific oyster Crassostrea gigas. Mar Biol 106:379-387

*Cushing DH (1990) Plankton production and year-class strength in fish populations: an update of the match/mismatch hypothesis. Adv Mar Biol 26:249-293

Dame RF (2011) Ecology of marine bivalves: an ecosystem approach, 2nd edn. CRC Press, Boca Raton, FL

De Jonge VN, Elliott M (2001) Eutrophication. In: Steele J, Thorpe S, Turekian K (eds) Encyclopedia of ocean sciences, Vol. 2. Academic Press, London, p 852-870

Debos MJ, Mazard P, Blasco E (1972) L'introduction de Crassostrea gigas Thunberg dans les bassins d'Arcachon et de Thau. Mémoire de Maîtrise, Montpellier

Deslous-Paoli JM, Héral M, Berthomé JP, Razet D, Garnier J (1982) Reproduction naturelle de Crassostrea gigas Thunberg dans le bassin de Marennes-Oléron en 1979 et 1981: aspects biochimiques et énergétiques. Rev Trav Inst Peches Marit 45:319-327 
Deslous-Paoli JM, Mazouni N, Souchu P, Landrein S, Pichot $\mathrm{P}$, Juge C (1993) Oyster farming impact on the environment of a Mediterranean lagoon (THAU) (Preliminary results of the OXYTHAU programme). In: Dame RF (ed) Bivalve filter feeders in estuarine and coastal ecosystem processes. Springer, Berlin, p 519-521

Douillet P (1993) Bacterivory in Pacific oyster Crassostrea gigas larvae. Mar Ecol Prog Ser 98:123-134

Drullion D (2002) Etude qualitative et quantitative du cycle de reproduction del'huître creuse, Crassostrea gigas Thunberg, dans la lagune de Thau. Rapport de Maïtrise, Sète

Duarte CM, Conley DJ, Carstensen J, Sánchez-Camacho M (2009) Return to Neverland: shifting baselines affect eutrophication restoration targets. Estuaries Coasts 32: 29-36

* Dupuy C, Vaquer A, Lam-Höai T, Rougier C and others (2000) Feeding rate of the oyster Crassostrea gigas in a natural planktonic community of the Mediterranean Thau lagoon. Mar Ecol Prog Ser 205:171-184

* Dutertre M, Beninger PG, Barille L, Papin M, Haure J (2010) Rising water temperatures, reproduction and recruitment of an invasive oyster, Crassostrea gigas, on the French Atlantic coast. Mar Environ Res 69:1-9

Elston RA, Cheney D, Frelier P, Lynn D (1999) Invasive orchitophryid ciliate infections in juvenile Pacific and Kumomoto oysters, Crassostrea gigas and Crassostrea sikamea. Aquaculture 174:1-14

Enriquez-Diaz M, Pouvreau S, Chávez-Villalba J, Pennec M (2009) Gametogenesis, reproductive investment and spawning behavior of the Pacific giant oyster Crassostrea gigas: evidence of an environment-dependent strategy. Aquacult Int 17:491-506

Fabioux C, Huvet A, Le Souchu P, Le Pennec M, Pouvreau S (2005) Temperature and photoperiod drive Crassostrea gigas reproductive internal clock. Aquaculture 250: 458-470

Fiandrino A, Ouisse V, Dumas F, Lagarde F and others (2017) Spatial patterns in coastal lagoons related to the hydrodynamics of seawater intrusion. Mar Pollut Bull 119:132-144

* Glibert PM, Fullerton D, Burkholder JM, Cornwell JC, Kana TM (2011) Ecological stoichiometry, biogeochemical cycling, invasive species, and aquatic food webs: San Francisco estuary and comparative systems. Rev Fish Sci 19:358-417

Goulletquer P (1995) Cycle de reproduction naturelle de l'huître creuse Crassostrea gigas. In: Rapport due groupe de travail sur la reproduction naturelle et contrôlée des bivalves cultivés en France, 14-15 Novembre 1995. Ifremer, Nantes, p 7-19. http://archimer.ifremer.fr/doc/ 00000/3209/

Gowen RJ, Collos Y, Tett P, Scherer C and others (2015) Response of diatom and dinoflagellate lifeforms to reduced phosphorus loading: a case study in the Thau lagoon, France. Estuar Coast Shelf Sci 162:45-52

Grizel H, Héral M (1991) Introduction into France of the Japanese oyster (Crassostrea gigas). J Cons Cons Int Explor Mer 47:399-403

Grosberg RK, Levitan DR (1992) For adults only? Supplyside ecology and the history of larval biology. Trends Ecol Evol 7:130-133

Guelorget O, Perthuisot JP, Lamy N, Lefebvre A (1994) Structure and organization of Thau lagoon in terms of benthic fauna (macrofauna-meiofauna). Relations with confinement. Oceanol Acta 17:105-114
Héral M, Deslous-Paoli JM (1991) Oyster culture in European countries. In: Menzel W (ed) Estuarine and marine bivalve mollusk culture. CRC Press, Boca Raton, FL, p 153-190

His E, Robert R (1985) Développement des véligères de Crassostrea gigas dans le bassin d'Arcachon. Etude sur les mortalités larvaires. Rev Trav Inst Peches Marit 47: 63-88

*His E, Seaman MNL (1992) Effects of temporary starvation on the survival, and on subsequent feeding and growth, of oyster (Crassostrea gigas) larvae. Mar Biol 114:277-279

His E, Maurer D, Robert R (1986) Observations complementaires sur les causes possibles des anomalies de la reproduction de Crassostrea gigas (Thunberg) dans le bassin d'Arcachon. Rev Trav Inst Peches Marit 48:45-54

His E, Robert R, Dinet A (1989) Combined effect of temperature and salinity on fed and starved larvae of the Mediterranean mussel Mytilus galloprovincialis and the Japanese oyster Crassostrea gigas. Mar Biol 100:455-463

* Hothorn T, Hornik K, van de Wiel MA, Zeileis A (2006a) A Lego system for conditional inference. Am Stat 60: $257-263$

*Hothorn T, Hornik K, Zeileis A (2006b) CTREE: conditional inference trees. R package party, https://CRAN.R-project. org/web/packages/partykit/vignettes/ctree.pdf

Hubbard AB, Reidenbach MA (2015) Effects of larval swimming behavior on the dispersal and settlement of the eastern oyster Crassostrea virginica. Mar Ecol Prog Ser 535:161-176

* Hughes TP, Baird AH, Dinsdale EA, Moltschaniwskyj NA, Pratchett MS, Tanner E, Willis BL (2000) Supply-side ecology works both ways: the link between benthic adults, fecundity, and larval recruits. Ecology 81:2241-2249

Jarry V, Fiala M, Frisoni GF, Jacques G, Neveux J, Panouse M (1990) The spatial distribution of phytoplankton in a Mediterranean lagoon (Etang de Thau). Oceanol Acta 13: 503-512

Jeppesen E, Søndergaard M, Jensen JP, Mortensen E, Hansen AM (1998) Cascading trophic interactions from fish to bacteria and nutrients after reduced sewage loading: an 18-year study of a shallow hypertrophic lake. Ecosystems 1:250-267

Jeppesen E, Søndergaard M, Jensen JP, Havens KE and others (2005) Lake responses to reduced nutrient loading: an analysis of contemporary long-term data from 35 case studies. Freshw Biol 50:1747-1771

Jouffre D, Lamhoai T, Millet B, Amanieu M (1991) Spatial structuring of zooplankton communities and hydrodynamic pattern in coastal lagoons. Oceanol Acta 14: 489-504

Kennish MJ, Paerl HW (eds) (2010) Coastal lagoons, critical habitats of environmental change. CRC Press, Boca Raton, FL

Knoppers B (1994) Aquatic primary production in coastal lagoons. In: Kjerfve B (ed) Coast lagoon process. Elsevier, Amsterdam, p 243-286

KLagarde F, Fiandrino A, Richard M, Bernard I and others (2015a) Déterminisme du recrutement larvaire de l'huitre creuse Crassostrea gigas dans la lagune de Thau. Ifremer, Sète

* Lagarde F, Gervasoni E, Pérignon A, Mortreux S and others (2015b) Recherche de gisements de captage naturel de Crassostrea gigas en lagune de Thau. Répartition spatiotemporelle du naissain, aspects culturaux et économiques. Ifremer, Sète 
Lam-Hoai T, Rougier C, Lasserre G (1997) Tintinnids and rotifers in a northern Mediterranean coastal lagoon. Structural diversity and function through biomass estimations. Mar Ecol Prog Ser 152:13-25

Larsson AI, Granhag L, Jonsson P (2016) Instantaneous flow structures and opportunities for larval settlement: barnacle larvae swim to settle. PLOS ONE 11:e0158957

Lazure P, Dumas F (2008) An external-internal mode coupling for a 3D hydrodynamical model for applications at regional scale (MARS). Adv Water Resour 31:233-250

Leruste A, Malet N, Munaron D, Derolez V and others (2016) First steps of ecological restoration in Mediterranean lagoons: shifts in phytoplankton communities. Estuar Coast Shelf Sci 180:190-203

Lie AAY, Wong CK, Lam JYC, Liu JH, Yung YK (2011) Changes in the nutrient ratios and phytoplankton community after declines in nutrient concentrations in a semienclosed bay in Hong Kong. Mar Environ Res 71:178-188

Marie D, Partensky F, Jacquet S, Vaulot D (1997) Enumeration and cell cycle analysis of natural populations of marine picoplankton by flow cytometry using the nucleic acid stain SYBR Green I. Appl Environ Microbiol 63: 186-193

Mazouni N, Gaertner JC, Deslous-Paoli JM (1998) Influence of oyster culture on water column characteristics in a coastal lagoon (Thau, France). Hydrobiologia 373/374: $149-156$

Millet B, Cecchi P (1992) Wind-induced hydrodynamic control of the phytoplankton biomass in a lagoon ecosystem. Limnol Oceanogr 37:140-146

Miron G, Boudreau B, Bourget E (1995) Use of larval supply in benthic ecology: testing correlations between larval supply and larval settlement. Mar Ecol Prog Ser 124: 301-305

Mizuno K, Wakano M, Takatsuji H, Nagai T (2015) Effects of the dinoflagellate Karenia mikimotoi on larval settlement of Pacific oyster Crassostrea gigas. Bull Jpn Soc Sci Fish 81:811-816

Mu C, Li Q (2013) Effects of the dinoflagellate Alexandrium catenella on the early development of the Pacific oyster Crassostrea gigas. J Shellfish Res 32:689-694

Neveux J, Lantoine F (1993) Spectrofluorometric assay of chlorophylls and phaeopigments using the least squares approximation technique. Deep Sea Res I 40:1747-1765

Nixon SW (1995) Coastal marine eutrophication: a definition, social causes, and future concerns. Ophelia 41: 199-219

North EW, Schlag Z, Hood RR, Li M, Zhong L, Gross T, Kennedy VS (2008) Vertical swimming behavior influences the dispersal of simulated oyster larvae in a coupled particle-tracking and hydrodynamic model of Chesapeake Bay. Mar Ecol Prog Ser 359:99-115

Pechenik JA (2006) Larval experience and latent effects metamorphosis is not a new beginning. Integr Comp Biol 46:323-333

Pernet F, Barret J, Marty C, Moal J, Le Gall P, Boudry P (2010) Environmental anomalies, energetic reserves and fatty acid modifications in oysters coincide with an exceptional mortality event. Mar Ecol Prog Ser 401:129-146

Pernet F, Barret J, Le Gall P, Corporeau C and others (2012) Mass mortalities of Pacific oysters Crassostrea gigas reflect infectious diseases and vary with farming practices in the Mediterranean Thau lagoon, France. Aquacult Environ Interact 2:215-237

Pernet F, Lagarde F, Jeanné N, Daigle G and others (2014)
Spatial and temporal dynamics of mass mortalities in oysters is influenced by energetic reserves and food quality. PLOS ONE 9:e88469

*Petton B, Bruto M, James A, Labreuche Y, Alunno-Bruscia M, Le Roux F (2015) Crassostrea gigas mortality in France: the usual suspect, a herpes virus, may not be the killer in this polymicrobial opportunistic disease. Front Microbiol 6:686

*Pineda J, Porri F, Starczak V, Blythe J (2010) Causes of decoupling between larval supply and settlement and consequences for understanding recruitment and population connectivity. J Exp Mar Biol Ecol 392:9-21

* Plunket L, Hidu H (1978) The role of Uronema marinum (Protozoa) in oyster hatchery production. Aquaculture 15:219-225

Pouvreau S, Petton S, Queau I, Bellec G and others (2013) Observer, analyser et gérer la variabilité de la reproduction et du recrutement de l'huître creuse en France. Le Réseau VELYGER. Rapport annuel 2013. http://doi.org/ $10.13155 / 31091$

Pouvreau S, Maurer D, Auby I, Lagarde F and others (2016) VELYGER database: the oyster larvae monitoring French Project http://doi.org/10.17882/41888

R Core Team (2015) R: a language and environment for statistical computing. R Foundation for Statistical Computing, Vienna

*Raby D, Mingelbier M, Dodson JJ, Klein B, Lagadeuc Y, Legendre L (1997) Food-particle size and selection by bivalve larvae in a temperate embayment. Mar Biol 127: 665-672

REPHY (French Observation and Monitoring program for Phytoplankton and Hydrology in coastal waters) (2017). REPHY dataset - French Observation and Monitoring program for Phytoplankton and Hydrology in coastal waters. 1987-2016 Metropolitan data. SEANOE. www. seanoe.org.data/00361/47248/

Rico-Villa B, Le Coz JR, Mingant C, Robert R (2006) Influence of phytoplankton diet mixtures on microalgae consumption, larval development and settlement of the Pacific oyster Crassostrea gigas (Thunberg). Aquaculture 256:377-388

Rico-Villa B, Bernard I, Robert R, Pouvreau S (2010) A dynamic energy budget (DEB) growth model for Pacific oyster larvae, Crassostrea gigas. Aquaculture 305:84-94

Robert R, Sanchez JL, Perez-Parelle L, Ponis E, Kamermans P, O'Mahoney M (2013) A glimpse on the mollusc industry in Europe. Aquac Eur 38:5-11

Rose M (1933) Copépodes pélagiques. Faune de France 26, Paris

Saeck EA, O'Brien KR, Weber TR, Burford MA (2013) Changes to chronic nitrogen loading from sewage discharges modify standing stocks of coastal phytoplankton. Mar Pollut Bull 71:159-167

Sherr EB, Caron DA, Sherr BF (1993) Staining of heterotrophic protists for visualization via epifluorescence microscopy. In: Kemp PF, Sherr BF, Sherr EB, Cole JJ (eds) Handbook of methods in aquatic microbial ecology. Lewis Publishers, Boca Raton, FL, p 213-227

* Shimeta J, Cutajar J, Watson MG, Vlamis T (2012) Influences of biofilm-associated ciliates on the settlement of marine invertebrate larvae. Mar Ecol Prog Ser 449:1-12

Smith VH, Schindler DW (2009) Eutrophication science: Where do we go from here? Trends Ecol Evol 24:201-207

Sommer F, Stibor H, Sommer U, Velimirov B (2000) Grazing by mesozooplankton from Kiel Bight, Baltic Sea, on dif- 
ferent sized algae and natural seston size fractions. Mar Ecol Prog Ser 199:43-53

Souchu P, Vaquer A, Collos Y, Landrein S, Deslous-Paoli JM, Bibent B (2001) Influence of shellfish farming activities on the biogeochemical composition of the water column in Thau lagoon. Mar Ecol Prog Ser 218:141-152

Tagliapietra D, Ghirardini AV (2006) Notes on coastal lagoon typology in the light of the EU Water Framework Directive: Italy as a case study. Aquat Conserv 16:457-467

Thomas Y, Pouvreau S, Alunno-Bruscia M, Barillé L, Gohin F, Bryère P, Gernez P (2016) Global change and climatedriven invasion of the Pacific oyster (Crassostrea gigas) along European coasts: a bioenergetics modelling approach. J Biogeogr 43:568-579

Toupoint N, Gilmore-Solomon L, Bourque F, Myrand B, Pernet F, Olivier F, Tremblay R (2012a) Match/mismatch between the Mytilus edulis larval supply and seston quality: effect on recruitment. Ecology 93:1922-1934

Toupoint N, Mohit V, Linossier I, Bourgougnon N and others (2012b) Effect of biofilm age on settlement of Mytilus edulis. Biofouling 28:985-1001

Troussellier M, Deslous-Paoli JM (2001) Thau lagoon: a working site for the acquisition, integration and valorization of lagoon ecosystem knowledges. Oceanis 27:257-289

Troussellier M, Cahet G, Lebaron P, Baleux B (1993) Distribution and dynamics of bacterial production in relation

Editorial responsibility: Inna Sokolova,

Charlotte, North Carolina, USA to wind pertubations in a Mediterranean Lagoon. Limnol Oceanogr 38:193-201

* Ubertini M, Lagarde F, Mortreux S, Le Gall P and others (2017) Gametogenesis, spawning behavior and larval abundance of the Pacific oyster Crassostrea gigas in the Thau lagoon: evidence of an environment-dependent strategy. Aquaculture 473:51-61

Utermöhl H (1931) Neue Wege in der quantitativen Erfassung des Planktons (mit besonderer Berücksichtigung des Ultraplanktons). Verh Int Ver Theor Angew Limnol 5:567-595

*Veniot A, Bricelj V, Beninger P (2003) Ontogenetic changes in gill morphology and potential significance for food acquisition in the scallop Placopecten magellanicus. Mar Biol 142:123-131

Vethaak AD, Davies IM, Thain JE, Gubbins MJ and others (2017) Integrated indicator framework and methodology for monitoring and assessment of hazardous substances and their effects in the marine environment. Mar Environ Res 124:11-20

Wray GA (1995) Evolution of larvae and development modes. In: McEdward L (ed) Ecology of marine invertebrate larvae. CRC Press, Boca Raton, FL, p 413-447

Yanagi T (2015) Eutrophication and oligotrophication in Japanese estuaries: the present status and future tasks. Springer, Dordrecht

Submitted: March 7, 2017; Accepted: July 18, 2017

Proofs received from author(s): August 23, 2017 